\title{
Clinical utility and differential effects of prostaglandin analogs in the management of raised intraocular pressure and ocular hypertension
}

\author{
This article was published in the following Dove Press journal: \\ Clinical Ophthalmology \\ 8 July 2010 \\ Number of times this article has been viewed
}

\author{
Anne J Lee ${ }^{1,2}$ \\ Peter McCluskey ${ }^{2,3}$ \\ 'Manchester Royal Eye Hospital, \\ Manchester, UK; ${ }^{2}$ University \\ of Sydney, Sydney, Australia; ${ }^{3}$ Sydney \\ Eye Hospital, Sydney, Australia
}

Correspondence: Peter McCluskey Sydney Eye Hospital, 8 MacQuarie Street, Sydney NSW 2000, Australia Email pmccluskey@eye.usyd.edu.au

\begin{abstract}
Prostaglandin analogs (PGA) are powerful topical ocular hypotensive agents available for the treatment of elevated intraocular pressure (IOP). Latanoprost $0.005 \%$ and travoprost $0.004 \%$ are prodrugs and analogs of prostaglandin F2 $\alpha$. Bimatoprost $0.03 \%$ is regarded as a prostamide, and debate continues as to whether it is a prodrug. The free acids of all 3 PGAs reduce IOP by enhancing uveoscleral and trabecular outflow via direct effects on ciliary muscle relaxation and remodeling of extracellular matrix. The vast majority of clinical trials demonstrate IOP-lowering superiority of latanoprost, bimatoprost and travoprost compared with timolol $0.5 \%$, brimonidine $0.2 \%$, or dorzolamide $2 \%$ monotherapy. Bimatoprost appears to be more efficacious in IOPlowering compared with latanoprost, with weighted mean difference in IOP reduction documented in one meta-analysis of $2.59 \%$ to $5.60 \%$ from 1 - to 6-months study duration. PGAs reduce IOP further when used as adjunctive therapy. Fixed combinations of latanoprost, bimatoprost or travoprost formulated with timolol $0.5 \%$ and administered once daily are superior to monotherapy of its constituent parts. PGA have near absence of systemic side effects, although do have other commonly encountered ocular adverse effects. The adverse effects of PGA, and also those found more frequently with bimatoprost use include ocular hyperemia, eyelash growth, and peri-ocular pigmentary changes. Iris pigmentary change is unique to PGA treatment. Once daily administration and near absence of systemic side effects enhances tolerance and compliance. PGAs are often prescribed as first-line treatment for ocular hypertension and open-angle glaucoma.
\end{abstract}

Keywords: prostaglandin analog, glaucoma, ocular hypertension, latanoprost, bimatoprost, travoprost

\section{Introduction}

Glaucoma is a common and potentially blinding ocular disease of multifactorial etiology. It is characterized by progressive acquired loss of retinal ganglion cells leading to optic nerve atrophy and visual field deficits. An estimated 60.5 million people will have open-angle and angle-closure glaucoma by 2010, increasing to 79.6 million by 2020. ${ }^{1}$ Elevated intraocular pressure (IOP) is an important and modifiable risk factor for the development and progression of glaucoma. ${ }^{2}$ For each $\mathrm{mmHg}$ reduction in IOP estimated progression risk decreased by approximately $10 \%$. A 30\% IOP reduction has been shown to slow the rate of visual field progression among normal tension glaucoma (NTG) subjects. ${ }^{3}$ The Ocular Hypertension Treatment Study (OHTS) confirmed that a reduction of $20 \%$ is an acceptable response to treatment in ocular hypertension $(\mathrm{OH})$, and the risk of developing optic disc cupping and/or visual field loss in such cases decreased from $9.5 \%$ to $4.4 \% .{ }^{4}$ However, the magnitude of IOP reduction required for 
an individual is dependent on a number of factors including IOP level at which optic nerve damage occurs, the rate and extent of glaucomatous damage, patient life expectancy, and presence of other risk factors for glaucoma. ${ }^{5,6}$ With disease progression, the target IOP may change and is thus not static.

As newer agents with increased efficacy and tolerability are introduced into the armamentarium of topical ocular hypotensive medications, a new era of glaucoma management and declining glaucoma surgery rates is evolving. ${ }^{7}$ Topical $\beta$-adrenergic antagonists (both selective and nonselective derivatives) were initially introduced in $1978,^{7}$ followed by selective $\alpha_{2}$-adrenergic receptor agonists in 1988 and topical carbonic anhydrase inhibitors in $1995 .^{7}$ Isopropyl unoprostone (Rescula ${ }^{\circledR}$; CIBA Vision Ophthalmics, Bulach, Switzerland) was the first topical prostaglandin F2 $\alpha$ analog (PGA) commercially available, initially in Japan in $1994 .^{7}$ Of the more currently used prostaglandin analogues (PGAs), latanoprost 0.005\% (Xalatan ${ }^{\circledR}$; Pfizer Inc., New York, NY) was launched in 1996, followed by bimatoprost $0.03 \%$ (Lumigan ${ }^{\circledR}$; Allergan Inc., Irvine, CA) and travoprost $0.004 \%$ (Travatan ${ }^{\circledR}$; Alcon Inc., Ft Worth, TX) in 2001. ${ }^{7}$ Latanoprost and travoprost are both ester prodrugs of prostaglandin F2 $\alpha$ (PGF2 $\alpha$ ). Bimatoprost is the amide prodrug of 17-phenyl-PGF2 $\alpha$ and has been described as a prostamide, ${ }^{5,8-11}$ although controversial. ${ }^{12-15}$ This review will focus on the three most commonly used PGAs (latanoprost, travoprost and bimatoprost) for $\mathrm{OH}$ and open-angle glaucoma (OAG).

\section{Pharmacodynamic properties of prostaglandin analogs}

Latanoprost and travoprost are potent prodrug derivatives of naturally occurring PGF2 $\alpha$ and highly selective FP prostaglandin receptor agonists. The chemical structure of travoprost differs from latanoprost (13,14-dihydro-17-phenyl-18, 19, 20-trinor-PGF2 $\alpha$ isopropyl ester) by having a phenoxy group at carbon-16 and a trifluoromethyl group at the meta position on the phenoxy ring. ${ }^{7,16}$ Travoprost is the isopropyl ester of a single enantiomer of fluprostenol. ${ }^{17}$ Hydrolysis of the isopropyl ester to a biologically free and active carboxylic acid enables corneal penetration and agonism of the G-protein coupled FP receptor.

Bimatoprost is a PGF2 $\alpha$ analog where a neutral ethylamide substituent replaces the carboxylic acid. It appears to mimic the activity of prostamides, a newly discovered class of naturally occurring substances with inherent IOP lowering properties biosynthesized from endocannabinoid anandamide by the enzyme COX-2..$^{5,8-11,18,19}$ Bimatoprost increases outflow facility by $40 \%$ in human organ-cultured anterior segments within 48 hours of treatment and is blocked by AGN211334 a prostamide selective antagonist. ${ }^{20}$ Although bimatoprost is not regarded as a prodrug by some researchers, ${ }^{8,11}$ some human studies have detected bimatoprost free acid at levels high enough to activate the FP receptor. ${ }^{12-15}$ Lack of detection of the free acid at the site of action in other studies ${ }^{8,11}$ could be attributed to corneal esterase deficiency in some individuals, thus inability to convert the prodrug to the active free acid form. ${ }^{21}$

The free acids of latanoprost, bimatoprost and travoprost all fully and selectively activate the FP receptor relative to the naturally occurring agonist PGF2 $\alpha$, although receptor affinity is variable. Free acids of travoprost ${ }^{14,16}$ and bimatoprost ${ }^{14,15}$ are, respectively, approximately 10 and 3 to 10 times more potent in activating the FP receptor than latanoprost free acid. Travoprost concentration of $0.004 \%$ is slightly lower than latanoprost at $0.005 \%$, but probably represents a much higher dose on the dose-response curve. ${ }^{22}$ Bimatoprost concentration of $0.03 \%$ is 6 times that of latanoprost to allow sufficient conversion to its free acid to activate the FP receptor. Subsensitivity at the FP receptor level from either desensitization or down-regulation of the FP receptor ${ }^{23,24}$ could account for the observed reduced efficacy or even IOP increase with combination PGA therapy or increased frequency of PGA administration.

The exact mechanisms of action of PGAs are not entirely clear. Primate studies have shown that PGAs reduce IOP by enhancing uveoscleral ${ }^{25-28}$ and trabecular outflow with little or no effect on aqueous humor formation or episcleral venous pressure. ${ }^{7,10,20,21,26,29-31}$ Initial IOP reduction with PGAs may also be attributed to ciliary muscle relaxation via FP receptors, thus facilitating uveoscleral outflow. ${ }^{32}$ The presence of prostaglandins in trabecular meshwork cells ${ }^{31}$ and anterior segment organ cultures ${ }^{33}$ support a role in aqueous outflow regulation. Latanoprost acid infused human organ-cultured anterior segments significantly increased outflow facility at 24 hours (67\% vs 6\% controls). ${ }^{29}$ Proposed superior effects on trabecular outflow compared to uveoscleral outflow with bimatoprost ${ }^{26}$ or travoprost ${ }^{28}$ could be accounted for by measurement technique. ${ }^{34}$

PGAs appear to regulate matrix metalloproteinases (MMP) and tissue inhibitors of matrix metalloproteinases (TIMP) to modulate trabecular outflow resistance. MMPs are neutral zinc-dependent endoproteinases involved with normal and pathologic remodeling of extracellular matrix. Increased expression of MMP-1, -3, -17, and -24 and TIMP-2, $-3,-4^{35}$ 
in human trabecular meshwork cell cultures treated with latanoprost acid for 24 hours, and MMP-1, $-2,-3^{36}$ in iris root, ciliary muscle, and adjacent sclera in monkeys may lead to hydrolysis of collagen types I and III (MMP-1), collagen IV and fibronectin (MMP-2), and collagen types III, IV, fibronectin and laminin (MMP-3), resulting in widening of the connective tissue-filled spaces among the ciliary muscle bundles ${ }^{37}$ and loss of trabecular meshwork (TM) extracellular matrix, hence increased outflow. ${ }^{29,36}$ Similar anterior segment morphologic changes among the different prostaglandins, ${ }^{38}$ suggest similar mechanisms of action on uveoscleral or trabecular outflow. ${ }^{31}$ Studies to elucidate cellular mechanisms associated with PG-induced MMP secretion and alterations in calcium signaling pathways in the trabecular meshwork are ongoing.

A small (10\% to $15 \%)$ nocturnal increase in aqueous flow and uveoscleral outflow has been found from PGA use. ${ }^{25,39,40}$ Documented 24-hour efficacy of PGAs ${ }^{41-46}$ is important in reducing ischemic damage to the optic nerve caused by nocturnal episodes of systemic hypotension, especially in subjects with NTG. Topical $\beta$-blockers are unable to suppress aqueous secretion, hence reduce IOP, during sleep. ${ }^{47}$ Enhanced aqueous flow may also act to carry nutrients and remove waste products, important in the maintenance of anterior segment health. ${ }^{21}$

\section{Other effects}

Reduced or increased ocular blood flow (OBF) may respectively accelerate or prevent glaucomatous progression in some subjects. Latanoprost significantly increased pulsatile OBF in healthy volunteers, ${ }^{48,49}$ and $\mathrm{OAG}^{50,51}$ and $\mathrm{NTG}^{52-54}$ subjects, although not consistently found..$^{55}$ A randomized double-masked crossover study ${ }^{56}$ found a more favorable effect on ocular perfusion pressures (OPP) (which are directly related to $\mathrm{OBF}$ ) with latanoprost than timolol. ${ }^{56}$ Using color Doppler ultrasound, Koz et $\mathrm{al}^{57}$ demonstrated that latanoprost, travoprost and bimatoprost increased blood flow velocity and OPP, and latanoprost and travoprost decreased the resistive index of the ophthalmic artery and central retinal artery (CRA). Alagoz et $\mathrm{al}^{58}$ found increased CRA blood flow with bimatoprost and travoprost use. Other studies have found no change in blood flow velocity or vascular resistivity of the retrobulbar vessels with latanoprost. ${ }^{59-60}$ It is unclear if the effects on ocular hemodynamic parameters are related to IOP decrease or an independent phenomenon. Observation of conjunctival and scleral hyperemia with PGAs suggests vasodilatory actions, but vasoconstrictory effects may occur, often at higher concentrations.

\section{Pharmacokinetics of prostaglandin analogs}

After administration of a single drop $(30 \mu \mathrm{L})$ of tritium-labeled latanoprost $50 \mu \mathrm{g} / \mathrm{mL}$ (thus $1.5 \mu \mathrm{g}$ of drug), the maximum concentration of latanoprost averaged $32.6 \pm 20.6 \mathrm{ng} / \mathrm{mL}$ at 2.5 hours. $^{62}$ The elimination half-life of latanoprost acid from the aqueous humor was 2.5 hours. The concentration 24 hours after administration was $\leq 0.2 \mu \mathrm{g} / \mathrm{L}$. ${ }^{62}$ After one drop in each eye, the maximum plasma concentration of the free acid was $10^{-10} \mathrm{M}$ and the plasma half-life was 17 minutes. Latanoprost undergoes extensive first-pass metabolism in the liver via $\beta$-oxidation to its $(1,2)$-dinor and $(1,2,3,4)$-tetranor metabolites, then is eliminated by urine $(87.9 \%)$ and feces $(15.3 \%) .^{62}$

After one drop of travoprost $0.004 \%$ (1.2 $\mu \mathrm{g}$ of drug) in each eye, the maximum plasma concentration of the free acid was $10^{-10} \mathrm{M}$ and the plasma half-life 45 minutes (Travatan product information, Alcon). ${ }^{7}$ The free acid is metabolized to inactive metabolites via $\beta$-oxidation of the $\alpha$-chain to yield the 1, 2 dinor and 1,2,3,4, tetranor metabolites, via oxidation of the 15-hydroxyl moiety, as well as via reduction of the 13,14 double bond. Less than $2 \%$ of the topical ocular dose of travoprost was excreted in the urine within 4 hours as the travoprost acid. ${ }^{7}$

After one drop of bimatoprost $0.03 \%$ in each eye $(9 \mu \mathrm{g}$ of drug), the maximum plasma concentration of bimatoprost amide was approximately $10^{-10} \mathrm{M}$ (Lumigan product info, Allergan), peaked within 10 minutes of dosing and fell below the lower limit of detection within 1.5 hours. ${ }^{5}$ Mean maximum blood concentration and area under the curve values were similar on days 7 and 14 at $0.08 \mathrm{ng} / \mathrm{mL}$ and $0.09 \mathrm{ng} / \mathrm{h} / \mathrm{mL}$ respectively, indicating steady state levels after one week of ocular dosing. ${ }^{5}$ It is likely that bimatoprost enters the eye via the sclera as corneal tissue lacks specific amidases to form the active acid hydrolysis product. ${ }^{10}$ Bimatoprost levels were 10- to 100- times higher in the ciliary body and iris compared with aqueous humor. Bimatoprost undergoes oxidation, n-de-ethylation, and glucuronidation to form a diverse variety of metabolites. No drug accumulation occurs. Up to $67 \%$ of the administered dose was excreted in the urine whereas $25 \%$ was recovered in the feces. ${ }^{7}$

\section{Clinical efficacy and differential impact}

Studies of PGA therapy vary by way of randomization, masking, drug cross-over, patient selection, medication run-in and wash-out periods, and sponsorship. IOP measurement can be diurnal (usually mean of 3 daily measurements 
taken between 0800 and 1800 hours), investigated over a $12-63,64$ or $24-46,65,66$ hour period, and/or measured at specific time points (peak or trough). ${ }^{64,67,68}$ The primary endpoint in most trials is the mean reduction in IOP from baseline. Because of the large number of clinical studies of variable scientific quality evaluating latanoprost $0.005 \%$, bimatoprost $0.3 \%$ and travoprost $0.004 \%$ as mono-, concomitant or combination therapy for $\mathrm{OH}$ and $\mathrm{OAG},{ }^{63,64,68-83}$ selected randomized control trials and meta-analyses will be discussed in this review. Meta-analyses may be preferable in evaluating drug effectiveness. ${ }^{84}$ However, meta-analyses are unable to fully overcome heterogeneity of participant characteristics and IOP measurement time-points, and may be subject to publication bias with inclusion of unpublished data and often exclusion of non-English trials or lack of notating industry-sponsored trials. Quality of a meta-analysis depends on the quality of trials included. Selected meta-analyses involving PGAs as monotherapy are outlined in Table 1.

Selected multicenter, single- or double-blind, randomized control trials of greater than 1-month duration comparing the efficacy of prostaglandin analogues in $\mathrm{OH}$ and $\mathrm{OAG}$ are shown in Table 2 . The studies used various end-point parameters including mean IOP reduction, \%IOP reduction (\%IOPR) from baseline, or target IOP levels. Baseline demographic parameters were similar among groups within each study. Mean IOP reduction was similar for latanoprost, bimatoprost, and travoprost and documented at $8.6 \mathrm{mmHg}$, $8.7 \mathrm{mmHg}$, and $8.0 \mathrm{mmHg}$ respectively for one study. ${ }^{85}$ Four studies favored bimatoprost over latanoprost for IOP lowering. ${ }^{63,64,78,86}$ This was significant for 2 of the 4 studies. One of these studies found a significant difference only at 1200 and 1600 hours time-points, ${ }^{64}$ but the other study found a difference in IOP reduction between bimatoprost and latanoprost of 1.2 to $2.2 \mathrm{mmHg}$ at all measured time-points (0800, 1200, 1600 hours). ${ }^{86}$ Bimatoprost achieved target IOP $\leq 13 \mathrm{mmHg}^{64,86}$ or $\leq 15 \mathrm{mmHg}^{78}$ significantly more with than latanoprost. Bimatoprost also showed superiority over travoprost, but was significant only at the 0900 time-point; $\%$ IOP reduction from baseline for bimatoprost and travoprost was $27.9 \%$ and $23.3 \%$ respectively $(P=0.014) .{ }^{87}$ Travoprost was superior to latanoprost in another study; mean IOP was $0.8 \mathrm{mmHg}$ lower for travoprost vs latanoprost $(P=0.0191)$ and final IOP of $\leq 17 \mathrm{mmHg}$ or $\geq 30 \%$ IOP reduction was $54.7 \%$ and $49.6 \%$ for travoprost and latanoprost respectively $(P=0.0430) .{ }^{68}$

Several meta-analyses ${ }^{88-91}$ have directly compared the clinical efficacy of the three main PGAs, latanoprost, travoprost, and bimatoprost. Two independent meta-analyses, one $^{88}$ of $8^{63,64,68,78,85-87,92}$ and the other ${ }^{89}$ of 13 trials (including double-blind parallel ${ }^{57,63,93}$ or cross-over studies ${ }^{41,42}$ and single blind parallel ${ }^{64,78,85,86,94-96}$ or cross-over studies $)^{97}$ found bimatoprost was superior to latanoprost in lowering morning IOP at all time points, supported by a later posthoc meta-analysis of 2 independent trials with 6 months follow-up. Weighted mean difference (WMD) for \%IOP reduction $(\% \mathrm{IOPR})$ was $2.59 \%(P=0.004)$ at 1 month to $5.60 \%(P<0.001)$ at 6 months for one meta-analysis ${ }^{89}$ and weighted mean (WM) IOP change from baseline ranged from a minimum of $0.50 \mathrm{mmHg}(P=0.05)$ at 0800 hours to a maximum of $1.17 \mathrm{mmHg}(P<0.001)$ at 1200 hours in the other meta-analysis ${ }^{88}$ favoring bimatoprost over latanoprost. Bimatoprost was superior in IOP lowering to travoprost only during the daytime (0800 and 1200 hours time-points), but latanoprost and travoprost were comparable at all time points $(P \leq 0.82){ }^{88}$

An industry-sponsored meta-analysis ${ }^{90}$ of travoprost vs latanoprost (15 trials, $\mathrm{n}=1098),{ }^{57,68,85,93,95,96,98-100}$ travoprost vs bimatoprost ( 8 trials, $\mathrm{n}=714), 57,85,87,93,95,96,101,102$ and latanoprost vs bimatoprost ( 8 trials, $\mathrm{n}=943)^{57,64,85,86,93,95,96,103}$ found similar efficacy among the three PGAs. Studies comparing the PGA to other non-PGA glaucoma treatments, nonrandomized, dose-finding or cross-over trials, and short-term evaluations (less than 3 months) were excluded, although a trial evaluating timolol plus travoprost versus timolol alone, ${ }^{100}$ was included indicating that the PGA effect has the same relative effect as if it were compared with no treatment. Another industry-sponsored meta-analysis by Denis et $\mathrm{al}^{91}$ of 9 randomized trials ${ }^{63,68,78,85,86,92,93,101,104}(\mathrm{n}=1318)$ found adjusted IOP was similar for bimatoprost and travoprost, but more favorable than latanoprost treated subjects. Authors commented that 4 trials evaluating latanoprost vs timolol, were not included which may have lead to a lower IOP decrease for latanoprost compared with the meta-analysis by van der Valk. ${ }^{84}$

Four trials comparing latanoprost with unoprostone $0.15 \%$ twice daily for $1-2$ months demonstrated superiority with latanoprost. ${ }^{74,79,80,82}$ The mean IOP reduction was approximately twice as great with latanoprost as with unoprostone $(P<0.001)$, and 6-8 times as many latanoprost recipients achieved an IOP reduction $\geq 30 \%$ (44 and $45 \%$ vs 6 and $8 \%$; $P$ values not reported) in the two largest trials. ${ }^{80,82}$

In summary, bimatoprost appears to have superior IOP lowering effects over travoprost or latanoprost, ${ }^{63,64,78,86,88,89}$ with the ability to achieve lower target IOP, ${ }^{64,78,86}$ although not consistently found. ${ }^{85,90,91,105}$ 


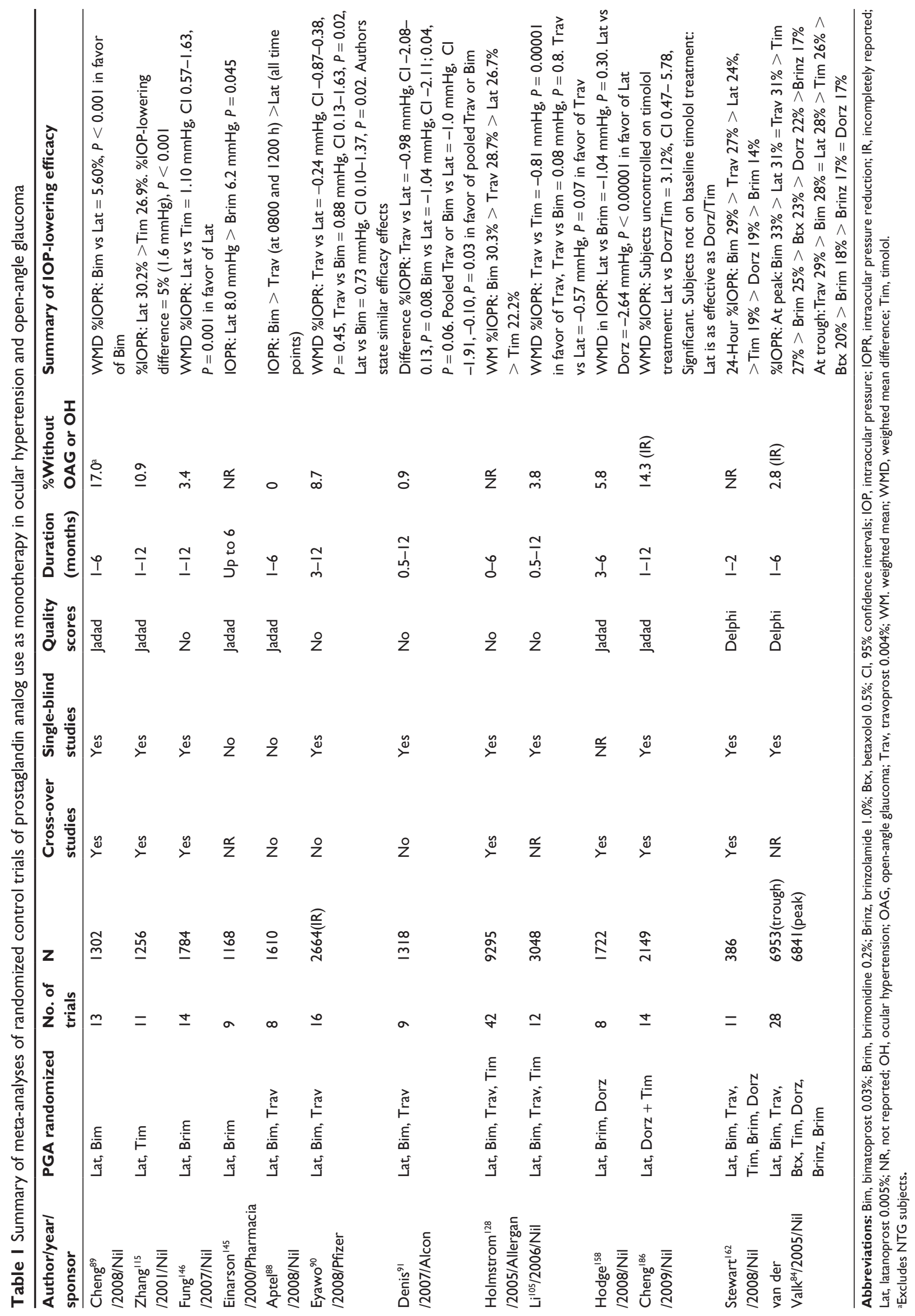




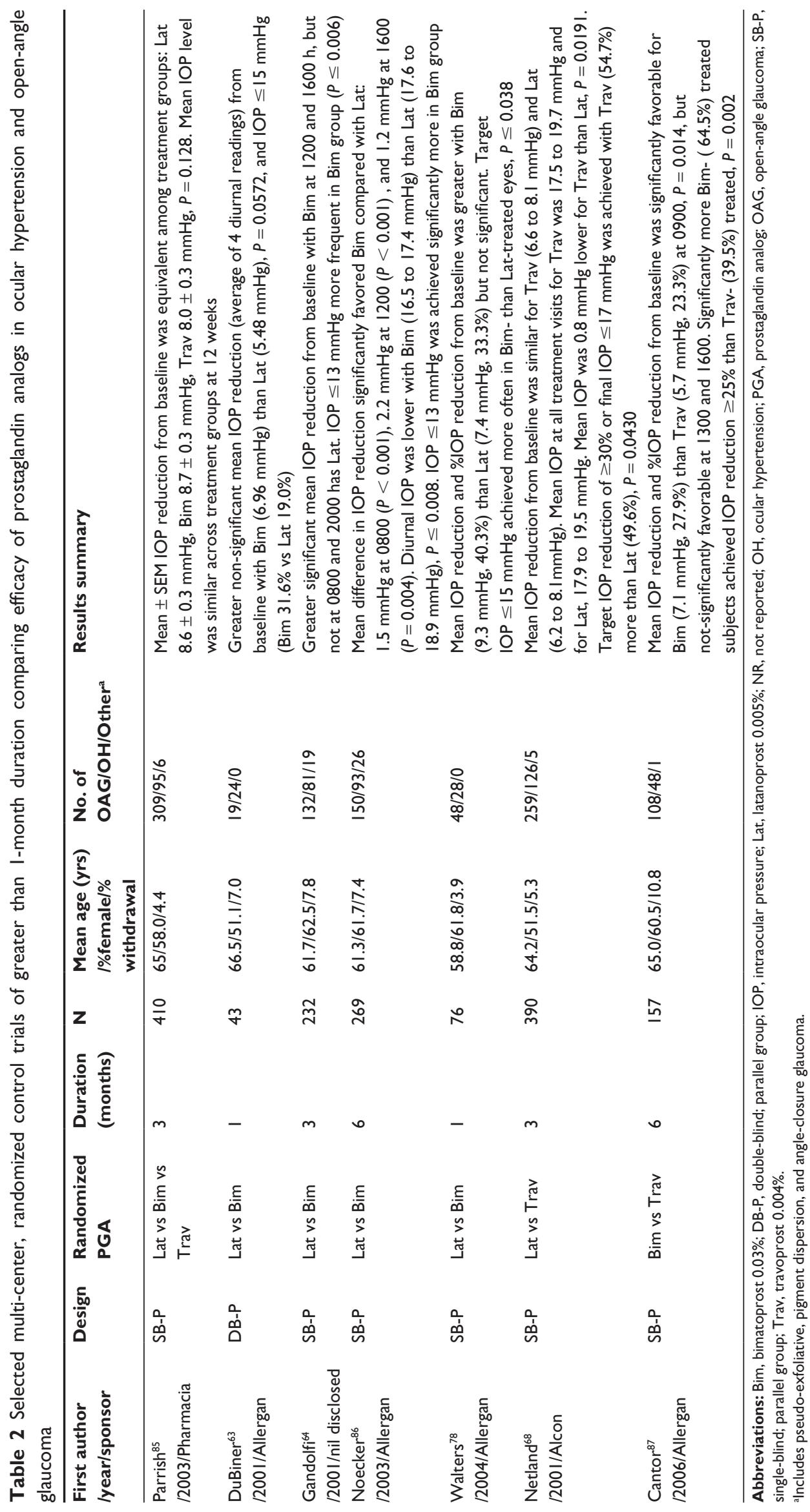




\section{Vs timolol}

Before the introduction of travoprost and bimatoprost, initial studies compared latanoprost $0.005 \%$ with other ocular hypotensives, in particular timolol $0.5 \%$. Table 3 shows the characteristics and results of double-blind randomized controlled trials comparing PGAs with timolol $0.5 \%$ twice daily for POAG and $\mathrm{OH}$.

Four of these studies ${ }^{71-73,81}$ evaluated latanoprost $0.005 \%$ and timolol $0.5 \%$ use in OH and POAG. Latanoprost reduced mean baseline diurnal IOP by 6.2 to $8.6 \mathrm{mmHg}$ (26.8\% to $35 \%)$ significantly more than timolol (4.4 to $8.3 \mathrm{mmHg}(19.9 \%$ to $32.7 \%)$ ) over $3^{81}$ or 6 months of treatment, ${ }^{71,73}$ except for the study by Watson et al ${ }^{72}$ which showed equivalence. Pooled analyses of 3 Phase III studies ${ }^{71-73}$ showed a mean diurnal IOP reduction of $7.7 \mathrm{mmHg}(31 \%)$ for latanoprost vs $6.5 \mathrm{mmHg}(26 \%)$ for timolol after 6 months, a significant difference of $1.2 \mathrm{mmHg}(18 \%), P<0.001106$ and no evidence of drift. ${ }^{107}$ Higher baseline diurnal IOP resulted in a larger diurnal reduction during treatment with both drugs $(P<0.001)$. A further decrease in morning IOP of $0.7 \mathrm{mmHg}(9 \%$, $P<0.001)$ at 6 weeks from the initial morning IOP reduction obtained at 2 weeks was found with latanoprost, ${ }^{106}$ which was maintained throughout 2 years of treatment, ${ }^{108}$ supported also by the 1- and 2-year extension trials of the
Phase III studies. ${ }^{109-112}$ The adjusted risk of IOP treatment failure was $8 \%$ overall, ${ }^{106} 3.6$ and 6.1 times significantly higher in the patients with a baseline untreated IOP of 26-29 and 30-45 mmHg respectively. Pooling 8 studies, ${ }^{113}$ the greatest difference in IOP lowering effect was observed with latanoprost in Mexican and Asian clinical trials. A prospective unmasked study $(\mathrm{n}=76)^{114}$ found latanoprost reduced IOP from $26.5 \pm 6.6 \mathrm{mmHg}$ to $17.4 \pm 2.7$ at 3 years in timolol unresponsive eyes.

An independent meta-analysis ${ }^{115}$ of 11 randomized headto-head trials ${ }^{56,61,71-73,81,116-120}(\mathrm{n}=1256)$ comparing timolol with latanoprost documented mean (SE) percentage IOP reductions (\%IOPR) from baseline of $31.2 \%(2.3)$ and $26.9 \%$ (3.4) for latanoprost and timolol respectively at 3 months, a significant difference in reduction of 5.0\% (95\% confidence interval $[\mathrm{CI}] 2.8,7.3), P=0.00$, and a similar difference at 6 months. ${ }^{115}$

The International Travoprost Study Group ${ }^{121}$ (see Table 3) found travoprost $0.004 \%$ reduced mean diurnal IOP by 8.0 to $8.9 \mathrm{mmHg}$, significantly more than timolol (6.3 to $7.9 \mathrm{mmHg}$ ), $P \leq 0.001$. Based on intent-to-treat data, the Travoprost Study Group ${ }^{122}$ also found a statistically significant mean IOP change from baseline for travoprost $0.004 \%$ ( -6.5 to $-7.1 \mathrm{mmHg}$ ) than for timolol $0.5 \%$ twice daily $(-5.2$ to $-6.8 \mathrm{mmHg})$. Higginbotham et al ${ }^{123}$

Table 3 Characteristics of double-blind randomized control trials of I to 9 months' duration comparing prostaglandin analogs with timolol $0.5 \%$ twice daily for ocular hypertension and open-angle glaucoma

\begin{tabular}{|c|c|c|c|c|c|c|c|c|c|}
\hline \multirow[t]{2}{*}{$\begin{array}{l}\text { Author/yearl } \\
\text { location }\end{array}$} & \multirow[t]{2}{*}{ Design } & \multirow[t]{2}{*}{$\begin{array}{l}\text { Randomized } \\
\text { PGA }\end{array}$} & \multirow[t]{2}{*}{$\begin{array}{l}\text { Duration } \\
\text { (months) }\end{array}$} & \multirow[t]{2}{*}{$\mathbf{N}$} & \multirow[t]{2}{*}{$\begin{array}{l}\text { Mean age }(y r s) / \\
\% \text { female } / \% \\
\text { withdrawal }\end{array}$} & \multirow[t]{2}{*}{$\begin{array}{l}\text { No. of OAG/ } \\
\text { OH/Other }\end{array}$} & \multicolumn{2}{|c|}{$\begin{array}{l}\text { \% diurnal IOP } \\
\text { reduction from } \\
\text { baseline }\end{array}$} & \multirow[t]{2}{*}{$P$-value } \\
\hline & & & & & & & PGA & Timolol & \\
\hline $\mathrm{Alm}^{71} / 1995 /$ & DB-P & Lat mane or & 6 & 267 & $67 / 56.6 / 6$ & $91 / 123 / 53$ & 35 (nocte) & 27 & $P=0.001$ \\
\hline Scand ${ }^{b}$ & DB-C & nocte & & & & & 3I (mane) & & \\
\hline $\begin{array}{l}\text { Camras }^{73} / 1996 / \\
\text { USA }^{b}\end{array}$ & DB-P & Lat nocte & 6 & 268 & $62 / 57.5 / 7$ & $84 / 170 / 14$ & 27 & 20 & $P=0.001$ \\
\hline $\begin{array}{l}\text { Watson }{ }^{72} / 1996 / \\
\text { UK }^{b}\end{array}$ & DB-P & Lat nocte & 6 & 294 & $65 / 35.0 / 9$ & $12|/| 48 / 25$ & 33.7 & 32.7 & NS \\
\hline $\begin{array}{l}\text { Mishima }{ }^{81 / 1996 /} \\
\text { Japan }\end{array}$ & DB-P & Lat mane & 3 & 178 & $57 / 51.1 / 11$ & NR & 26.8 & 19.9 & $P<0.001$ \\
\hline $\begin{array}{l}\text { Brandt }{ }^{124} / 200 \mathrm{I} / \\
\text { USA }^{\mathrm{b}}\end{array}$ & DB-P & $\begin{array}{l}\text { Bim nocte or } \\
\text { bd }\end{array}$ & 3 & 596 & $62 / 56.0 / 7.4$ & $373 / 218 / 5$ & $\begin{array}{l}35.2 \text { (nocte) } \\
30.4 \text { (bd) }\end{array}$ & 26.2 & $P<0.001$ \\
\hline $\begin{array}{l}\text { Whitcup }{ }^{125} / 2003 / \\
\text { USA }\end{array}$ & DB-P & $\begin{array}{l}\text { Bim nocte or } \\
\text { bd }\end{array}$ & 3 & 602 & $61 / 53.7 / 8.6$ & $300 / 284 / 18$ & $\begin{array}{l}32.4 \text { (nocte) } \\
25.2 \text { (bd) }\end{array}$ & 22.7 & $P<0.001$ \\
\hline $\begin{array}{l}\text { Goldberg'21/200I/ } \\
\text { Various }{ }^{b}\end{array}$ & DB-P & Trav nocte & 9 & 382 & 63/49.7/3.1 & $208 / / 47 / 27$ & $30.8-31.6$ & $25.1-27.9$ & $P \leq 0.000 \mathrm{I}$ \\
\hline $\begin{array}{l}\text { Fellman }{ }^{122} / 2002 / \\
\text { USA }^{b}\end{array}$ & DB-P & Trav nocte & 6 & 396 & $\mathrm{NR} / 52.5 / 2.8$ & $251 / 132 / 13$ & $\begin{array}{l}\text { From pooled } \\
\text { was superior }\end{array}$ & $\begin{array}{l}\text { isits, Trav } \\
\text { o Tim }\end{array}$ & $P<0.0130$ \\
\hline
\end{tabular}

Abbreviations: bd, twice daily; Bim, bimatoprost 0.03\%; DB-C, double-blind, cross-over; DB-P, double-blind, parallel; Lat, latanoprost 0.005\%; mane, every morning; nocte, every night; NR, not recorded; NS, not significant; OH, ocular hypertension; OAG, open-angle glaucoma; PGA, prostaglandin analog; Scand, Scandinavia; Trav, travoprost 0.004\%; wks, weeks; Tim, timolol.

alncludes pseudoexfoliative, pigment dispersion and other secondary glaucomas; bindicates sponsorship by Pharmacia Inc. 
pooled 1-year results from the Bimatoprost Study Groups $1^{124}$ and $2^{125}(\mathrm{n}=1198)$ found bimatoprost $0.03 \%$ once daily was more efficacious than bimatoprost $0.03 \%$ or timolol $0.5 \%$ twice daily. ${ }^{123}$ An IOP $\leq 17 \mathrm{mmHg}$ was achieved in $58 \%$ of bimatoprost once daily patients compared with $37 \%$ of timolol treated subjects. Bimatoprost lowered IOP to the same extent in blacks and non-blacks, while timolol was less effective in blacks (by approximately $2 \mathrm{~mm}$ ). Mean reduction with bimatoprost $0.03 \%$ once daily was sustained over $2^{126}$ and $4^{127}$ years, and remained lower than timolol $(P \leq 0.001)$.

Holmstrom et al ${ }^{128}$ analyzed efficacy of latanoprost (33 studies), bimatoprost (18 studies) and travoprost (8 studies) monotherapy, and combined latanoprost/timolol (11 studies), bimatoprost/brimonidine (1 study), and travoprost/timolol (2 studies). Difference in \%IOPR was 6\%; IOPR \% was $27.2 \%$ for PGA use (collectively) $63,64,67,68$, 71-73,78,80-82,85,86,92,116,117,119,121,122,124,125,129-143 compared with $21.2 \%$ for timolol ${ }^{67,68,71-73,78,81,116,117,119,121,122,124-126,131,134,135,137,139,142,143}$ with 0 - to 1 -month data, and $22.2 \%$ and $28.6 \%$ for timolol and PGA respectively for studies with 0 - to 6-months data. Pooling all data ${ }^{128}$ the WM \%IOPR was $30.3 \%, 28.7 \%$, and $26.7 \%$ for bimatoprost, travoprost, and latanoprost respectively. Latanoprost studies had a lower baseline IOP (WM baseline IOP $24.84 \mathrm{mmHg}$ ) compared with bimatoprost $(25.74 \mathrm{mmHg}$ ) or travoprost $(26.83 \mathrm{mmHg})$, possibly due to a larger percentage of patients with run-in timolol treatment $(16 \%, 5 \%$ and $0 \%$ for latanoprost, bimatoprost and travoprost respectively). Another meta-analysis ${ }^{105}$ found travoprost $0.004 \%$ was equivalent in lowering IOP compared with bimatoprost $0.03 \% 85,86,92,93,95(\mathrm{WMD}=0.08, P=0.8)$ or latanoprost $0.005 \%{ }^{68,85,93,95,98,104}(\mathrm{WMD}=-0.57, P=0.07)$, but superior to timolol. ${ }^{68,121,122,144}$

In summary, the vast majority of studies support IOPlowering superiority of latanoprost, ${ }^{71,73,81,106}$ travoprost, ${ }^{121,122}$ and bimatoprost, ${ }^{124,125,137}$ over timolol, and although not entirely consistent. ${ }^{72}$ PGAs were effective in eyes unresponsive or inadequately controlled with timolol, and remained effective long term.

\section{Vs brimonidine}

Two meta-analyses ${ }^{145,146}$ comparing efficacy of latanoprost and brimonidine both favored latanoprost for IOP lowering. ${ }^{145}$ In one meta-analysis, ${ }^{145}$ the estimated absolute decrease in IOP from baseline for latanoprost and brimonidine was respectively -8.4 and $-6.5 \mathrm{mmHg}$ at 3 months $(P=0.004)$ and -8.0 and $-6.2 \mathrm{mmHg}$ at 6 months $(P=0.045)$. Head-to-head trials post-dated the study hence studies comparing the medication in question and timolol $^{71-73,81,116,119,147,148}$ or betaxolol ${ }^{149}$ were included. In contrast, head-to-head trials, ${ }^{43,52,53,59,70,76,77,83,150-157}$ only were analyzed for the second meta-analysis. ${ }^{146}$ The pooled summary estimate significantly favored latanoprost (weighted mean difference $(\mathrm{WMD})=1.10,95 \% \mathrm{CI} 0.57$ to 1.63 ) over brimonidine. A third meta-analysis ${ }^{158}$ did not find a significant reduction in mean IOP when latanoprost was compared with brimonidine (WMD $=-1.04 ; P=0.30$ ). This pooled result did not change when only two higherquality studies ${ }^{70,76}$ were analyzed; one study part funded by Pharmacia ${ }^{70}$ favored latanoprost (adjusted mean diurnal IOP reduction $=5.7 \mathrm{mmHg})$ over brimonidine $(3.1 \mathrm{mmHg})$ and the other study supported by Allergan ${ }^{76}$ did not find a significant difference between treatments; mean \%IOPR was $27.8 \%$ vs $27.0 \%$ for latanoprost and brimonidine respectively. Clinical success (based on IOP lowering efficacy, tolerability and patient satisfaction) at 3 months was greater with the brimonidine group (91\% vs $74 \%$, $P=0.01),{ }^{76}$ although the former study ${ }^{70}$ experienced 5 times more adverse effects from brimonidine use. In summary, 2 of 3 meta-analyses found improved efficacy of latanoprost than brimonidine in IOP lowering.

\section{Vs dorzolamide}

Hodge et al ${ }^{158}$ also compared latanoprost with dorzolamide through a meta-analysis of 3 studies $^{75,159,160}(\mathrm{n}=328)$. Mean IOP was lower in the latanoprost compared with the dorzolamide group (WMD $=-2.64 \mathrm{mmHg} ; P<0.00001)$. The largest of the studies analyzed ${ }^{75}$ documented a significant lowering of diurnal IOP with latanoprost $(8.5 \mathrm{mmHg})$ than dorzolamide $(5.6 \mathrm{mmHg} ; P<0.001){ }^{75}$

\section{Rank order of ocular hypotensives as monotherapy}

Pooled one-month IOP-lowering effect from baseline to peak $(n=6953)$ and trough $(n=6841)$ of 8 commonly used ocular hypotensives was reported by van der Valk et al. ${ }^{84}$ At peak, greatest \%IOPR was achieved by bimatoprost (33\%), followed by latanoprost (31\%), travoprost (31\%), timolol (27\%), brimonidine (25\%), betaxolol (23\%), dorzolamide (22\%), brinzolamide (17\%), and a placebo (5\%). At trough, greatest $\%$ IOPR was achieved by travoprost $(29 \%)$, followed by bimatoprost (28\%), latanoprost (28\%), timolol (26\%), betaxolol $(20 \%)$, brimonidine (18\%), brinzolamide (17\%), and dorzolamide (17\%). A network meta-analysis also by van der Valk ${ }^{161}$ found mean IOP reduction at peak was greatest with bimatoprost, travoprost and latanoprost, followed by other ocular hypotensive agents, and at trough 
bimatoprost, latanoprost, and travoprost followed by other ocular hypotensive agents.

Stewart et $\mathrm{al}^{162}$ evaluated studies of ocular hypotensive therapy efficacy measured over 24 hours. Greatest 24-hour IOP reduction was found with bimatoprost (29\%) and travoprost (27\%) than latanoprost (24\%), combination dorzolamide and timolol (19\%), or brimonidine (14\%). Mean reduction of night-time points was statistically lower than that of day time points for latanoprost $(P=0.031)$, timolol $(P=0.032)$, and brimonidine $(P=0.050)$ but not for dorzolamide $(P=0.60)$, bimatoprost $(P=0.057)$ and travoprost $(P=0.064)$. Latanoprost showed greater 24 -hour efficacy with night dosing (24\%) than morning dosing (18\%). For travoprost, there was no a significant difference between night $(27 \%)$ or morning $(26 \%)$ dosing $(P=0.074)$.

Twenty-four-hour IOP measurements may provide better information for clinical decision-making than daytime IOPs alone. ${ }^{162}$ Higher peak pressure ${ }^{163,164}$ may be an independent risk factor for glaucomatous progression and IOP measurements outside normal office hours can change the peak pressure assessment in $69 \%$ to $75 \%$ of cases. ${ }^{165,166}$ In other studies, mean reductions in IOP were lower with latanoprost than with timolol $0.5 \%$ during both the daytime and night-time hours $(P \leq 0.05)^{46,66}$ as timolol did not reduce IOP as much at night $(P=0.04){ }^{66}$ Flattening of the 24-hour IOP curve, thus reduction in IOP fluctuations was documented for bimatoprost ${ }^{63,143,163}$ and latanoprost, ${ }^{168}$ importantly for NTG subjects in the latter. The 24-hour diurnal IOP was statistically lower with bimatoprost compared with latanoprost in a double-masked cross-over comparison $(n=42)$, although the difference was small and latanoprost better tolerated with regard to conjunctival hyperemia. ${ }^{41}$

However, for NTG a meta-analysis ${ }^{169}$ found IOP reduction was greatest for brimonidine (24\%), followed by bimatoprost (21\%), latanoprost (20\%), timolol (15\%), and dorzolamide (14\%) at peak, and greatest for latanoprost (20\%), followed by timolol (18\%) and bimatoprost (18\%), dorzolamide (12\%), and brimonidine (11\%) at trough. Ten of the 15 trials involved a PGA. $44,53,56,103,114,169,170-173$

Subjects $(n=1571)$ switched to latanoprost from previous glaucoma monotherapy and fixed and unfixed combination therapies maintained IOP to an acceptable level through a 2-year period. ${ }^{174}$ Latanoprost-insensitive patients developed IOP lowering with bimatoprost in a randomized prospective study with two 30-day treatment phase and 30-day washout phase. ${ }^{136}$ IOP on bimatoprost $(18.1 \pm 1.7 \mathrm{mmHg})$ was significantly lower than either baseline $(24.8 \pm 1.1 \mathrm{mmHg}$,
$P<0.0001)$ or latanoprost $(24.1 \pm 0.9 \mathrm{mmHg}, P=00001)$ when rechallenged.

In summary, all three PGAs have documented superiority over other ocular hypotensives in various meta-analyses with respect to $\% \mathrm{IOPR}^{84}$ and 24 -hour IOP reduction for $\mathrm{OH}$ and POAG. ${ }^{162} \%$ IOPR may be superior for brimonidine than PGA for NTG. ${ }^{169}$ PGAs are as effective for IOP-lowering at night-time as for day-time.

\section{Adjunctive therapy}

In timolol-treated subjects, adjunctive latanoprost lowered IOP significantly more than adjunctive dorzolamide (-7.06 $\mathrm{mmHg} ; 32 \%$ vs $-4.44 \mathrm{mmHg} ; 20 \%$ for adjunctive latanoprost and dorzolamide respectively) after 3-months in one study ${ }^{175}$ and more than adjunctive pilocarpine $2 \%, 3$ times daily in another. ${ }^{130,176,177}$ Addition of latanoprost to pilocarpine therapy does not appear to diminish uveoscleral outflow ${ }^{178,179}$ but is instead additive, ${ }^{178,180-183}$ contrary to thoughts that ciliary muscle contraction with cholinergics hinders uveoscleral outflow. ${ }^{179}$ In subjects $(\mathrm{n}=115)$ with uncontrolled IOP on $\beta$-blocker monotherapy, adjunctive latanoprost $(23.5 \%)$ or brimonidine $(22.8 \%)$ were comparable in\%IOPR at peak effect at one month, but brimonidine was better tolerated than latanoprost. ${ }^{151}$ As third-line agents, overall mean\%IOPR was not significantly different between brimonidine (22.8\%) and latanoprost (17.2\%), although brimonidine (85\%) had slightly higher although non-significant clinical success $(\geq 15 \%$ reduction in IOP from baseline) than latanoprost (65\%). ${ }^{152}$

An additive effect of latanoprost was seen in an openlabel 1-week trial of subjects with uncontrolled IOP on concomitant timolol and dorzolamide twice daily ${ }^{184}$ with an additional 16\% reduction in IOP, and a 3-month study of subjects with uncontrolled IOP on fixed combination dorzolamide/timolol (FCDT) with a further $5.2 \mathrm{mmHg}$ IOP reduction at peak and $3.5 \mathrm{mmHg}$ at trough. ${ }^{150} \mathrm{~A}$ retrospective analysis of 73 eyes with uncontrolled IOP on latanoprost documented better \%IOPR with adjunctive dorzolamide $(19.7 \%, P<0.001)$ than $\beta$-blockers $(12.3 \%, P<0.001)$ or brimonidine $(9.3 \%, P=0.0011){ }^{185}$

\section{Vs dual therapy}

A meta-analysis ${ }^{186}$ of 14 studies $^{43,50,60,99,133,187-195}(\mathrm{n}=2149)$ found latanoprost lowered diurnal mean IOP significantly more than concomitant dorzolamide/timolol (11/14 studies used FCDT) if subjects were uncontrolled on timolol monotherapy (WMD for mean \%IOPR was 3.12 (95\% CI, 0.47 to 5.78), but was of equal efficacy if no baseline timolol was given. Post-hoc analyses ${ }^{196}$ from 2 randomized, multicenter, 
double-masked trials ${ }^{133}$ comparing latanoprost with FCDT independent of baseline timolol use found equal efficacy for mean IOP at each time-point, mean IOP reduction for high IOP at baseline, and 40\% IOP reduction. FCDT and latanoprost have similar 24-hour IOP-lowering efficacy after 2-months, but latanoprost further reduced mean 24-hour IOP by $0.3 \mathrm{mmHg}(P=0.01)$ at 6 months. ${ }^{195}$

Bimatoprost decreased IOP from baseline by 6.8 to $7.6 \mathrm{mmHg}$, significantly more than FCDT (4.4 to $5.0 \mathrm{mmHg}$, $P<0.001)$ in a randomized 3-month double-masked trial of subjects $(n=177)$ inadequately controlled with timolol ${ }^{132}$ Subjects achieving IOP $\mathrm{s}$ of $\leq 13, \leq 14, \leq 15, \leq 16 \mathrm{mmHg}$ were more than twice as high for bimatoprost than for FCDT (all $P \leq 0.008$ ). Similar efficacy was found between bimatoprost $0.03 \%$ and concomitant timolol and latanoprost in a randomized 6 month investigator masked study of 56 subjects with a timolol run-in. ${ }^{140}$ To date, there are no published studies evaluating the efficacy of fixed or unfixed combinations of brimonidine/timolol with latanoprost, travoprost or bimatoprost.

\section{PGA/timolol fixed combinations}

Diurnal IOP levels were lower with fixed combination latanoprost $0.005 \% /$ timolol $0.5 \%$ (FCLT) solution (Xala$\operatorname{com}^{\circledR}$; Pfizer Inc., NY, NY) (19.9 $\left.\pm 3.4 \mathrm{mmHg}\right)$, compared with timolol $(23.4 \pm 5.4 \mathrm{mmHg})$ and latanoprost $(20.8 \pm 4.6 \mathrm{mmHg})$ monotherapy in a 6-month doublemasked trial $(n=418) .{ }^{137}$ The mean 24-hour diurnal curve was $19.2 \pm 2.6 \mathrm{mmHg}$ for latanoprost alone vs $16.7 \pm 2.1 \mathrm{mmHg}$ for FCLT in another trial. ${ }^{197}$ A meta-analysis of randomized clinical trials of 1 to 3 months' duration ${ }^{198}$ documented greater pooled IOP change from baseline with concomitant latanoprost and timolol $(-6.0 \mathrm{mmHg}),{ }^{67,130,176}$ than FCLT $(-3.0 \mathrm{mmHg}),{ }^{137,142}$ concomitant dorzolamide and timolol $(-4.1 \mathrm{mmHg}$ at trough and $-4.9 \mathrm{mmHg}$ at peak), or FCDT $(-3.8 \mathrm{mmHg}$ at trough and $-4.9 \mathrm{mmHg}$ at peak). Omission of the evening timolol dose with FCLT possibly explains the large difference in IOP between fixed and concomitant use. Studies evaluating add-on therapy pre-selects patients with higher untreated IOP or those unresponsive to timolol. Only one study reported the pre-run-in IOP. ${ }^{198}$ No measurement of expected peak latanoprost effect was made for studies on FCLT, whereas at least 1 measurement at the expected peak latanoprost effect for studies evaluating concomitant treatment was done. ${ }^{198}$ Subjects $(n=325)$ with inadequate IOP control (IOP $>16 \mathrm{mmHg}$ ) on mono- or dual therapy had lower diurnal IOP with FCLT (16.9 mmHg) than concomitant brimonidine and timolol (18.2 $\mathrm{mmHg})$,
$P<0.001$, at 6 months, ${ }^{156}$ also supported by a cross-over study with a 1-month timolol run-in period. ${ }^{154}$

Data from 3 Phase III clinical studies ${ }^{199,200}$ have shown that the fixed combination of bimatoprost $0.03 \% /$ timolol $0.5 \%$ (FCBT) ophthalmic solution (Ganfort ${ }^{\circledR}$; Allergan inc., Irvine, CA) was significantly more effective in lowering IOP, with a higher percentage achieving mean reduction in diurnal IOP of $>20 \%$ or a target pressure of $<18 \mathrm{mmHg}$, than timolol or bimatoprost monotherapy. From the pooled analysis of 2 trials, ${ }^{199}$ mean reduction in IOP from baseline was 7.4 to $9.6 \mathrm{mmHg}$ in the FCBT group, 6.7 to $8.8 \mathrm{mmHg}$ in the bimatoprost group, and 5.2 to $7.4 \mathrm{mmHg}$ in the timolol treated group. Some subjects were unresponsive to timolol prior to the study and one study had a run-in period of timolol twice daily. FCBT was non-inferior to concomitant administration of its component parts in a randomized, double blind, 3-week study of patients with $\mathrm{OAG}$ or $\mathrm{OH}$ naïve to treatment. ${ }^{201}$ Mean diurnal IOP was $16.1 \mathrm{mmHg}$ with FCBT, $15.6 \mathrm{mmHg}$ with concomitant bimatoprost and timolol, and $17.1 \mathrm{mmHg}$ with bimatoprost monotherapy. ${ }^{201}$ Two randomized, parallel group 4-202 and 12-week ${ }^{203}$ studies found FCBT was superior to FCLT in reducing mean diurnal IOP versus baseline at each time point. In the 12 -week study, ${ }^{203}$ more subjects had a mean IOP reduction from baseline of $\geq 20 \%$ with FCBT than FCLT (61.7\% vs 17.1\%). Subjects in both studies were insufficiently controlled on PGA, and there was no wash-out period.

Fixed combination travoprost $0.004 \%$ /timolol $0.5 \%$ (FCTT) ophthalmic solution $\left(\right.$ Duotrav $^{\circledR}$; Alcon Inc., Fort Worth, TX) lowered IOP 1.9 to $3.3 \mathrm{mmHg}$ more than timolol alone and $0.9-2.4 \mathrm{mmHg}$ more than travoprost alone. ${ }^{144}$ Adverse events rates were comparable. FCTT lowered absolute IOP level $(2.4 \mathrm{mmHg})$ for the 24-hour curve and at all time points, compared with travoprost $(P \leq 0.047)$, and the mean 24-hour IOP fluctuation was lower with FCTT $(3.0 \mathrm{mmHg}$ ) compared with travoprost $(4.0 \mathrm{mmHg}$, $P=0.001) .{ }^{204}$ FCTT had similar efficacy to concomitant travoprost and timolol. ${ }^{205}$ Mean differences between FCTT and concomitant treatment was \pm 0.4 to $\pm 1.1 \mathrm{mmHg}$. Percent IOP reduction from baseline was $29.1 \%$ to $33.2 \%$ for combination, $31.5 \%$ to $34.8 \%$ for concomitant, and $19.3 \%$ to $27.0 \%$ for timolol therapy alone. ${ }^{205}$ These findings are also supported by a 3-month study of 316 patients. ${ }^{206}$ FCTT did not demonstrate significant differences in mean IOP or mean IOP change from baseline compared with concomitant latanoprost and timolol in 2 studies. ${ }^{207,208}$ A 12-month randomized control, parallel-group trial showed statistically equal or better mean IOP for FCTT (16.4 to $17.1 \mathrm{mmHg}$ ) than 
FCLT (16.7 to $17.7 \mathrm{mmHg}$ ), ${ }^{100}$ supported by a retrospective, cross-sectional study. ${ }^{210}$ However, ocular hyperemia rates were higher with FCTT (15\%) compared with FCLT (2.5\%). ${ }^{100}$ Compared with FCDT, mean pooled diurnal IOP was significantly lower with FCTT $(16.5 \pm 0.23 \mathrm{mmHg}$ vs $17.3 \pm 0.23 \mathrm{mmHg} ; P=0.011)$ in a randomized-control, parallel, double-masked trial $(\mathrm{n}=319) .{ }^{209}$ FCTT produced mean IOP reductions of $35.3 \%$ to $38.5 \%$, FCDT reduced IOP $32.5 \%$ to $34.5 \%$. There do not appear to be studies directly comparing FCTT with FCBT.

In summary, fixed combinations of PGA with timolol are superior to monotherapy with its constituent parts. ${ }^{137,144,199}$ Non-inferiority compared with the unfixed combination was found for $\mathrm{FCBT}^{201}$ and $\mathrm{FCTT},{ }^{205}$ though not for FCLT. ${ }^{198}$ FCBT and FCTT appear to be more efficacious than FCLT.

\section{Adverse effects}

Table 4 shows differential rates of adverse events among the 3 main PGAs as reported in the randomized control trials summarized in Table 2.

\section{Ocular adverse events}

\section{Conjunctival hyperemia}

Conjunctival hyperemia was the most common adverse effect from PGAs observed in several studies. ${ }^{64,78,85-87,123}$ All studies outlined in Table 4 show significantly higher rates of ocular hyperemia with bimatoprost and travoprost compared with latanoprost, except one. ${ }^{63}$ Travoprost and bimatoprost have similar rates. ${ }^{87,211} \mathrm{~A}$ meta-analysis of 13 randomized control trials found reduced rates of ocular hyperemia in subjects using latanoprost than both travoprost (odds ratio $[\mathrm{OR}]=0.51 ; 95 \% \mathrm{CI} 0.39$ to $0.67, P<0.0001)$ or bimatoprost $(\mathrm{OR}=0.32 ; 95 \%$ CI 0.24 to $0.42, P<0.0001) .{ }^{211}$ Ocular hyperemia rates of $49.5 \%$ for travoprost, $27.6 \%$ for latanoprost, and $14 \%$ for timolol $0.5 \%$ have also been reported. ${ }^{17}$

Hyperemia was generally mild in severity, began within 2 days after starting PGA and diminished around 2 to 4 weeks, although may persist over time. ${ }^{85,123}$ Discontinuation rates due to hyperemia were $3.4 \%$ for bimatoprost daily $(5.6 \%$ for twice daily dosing), and $0.4 \%$ for timolol. Variability in the occurrence of hyperemia among those treated with PGAs may reflect a chemical difference in their molecular structure. ${ }^{213}$

Table 4 Differential adverse event rates among prostaglandin analogs as reported in multi-center, randomized control trials summarized in Table 2

\begin{tabular}{|c|c|c|c|}
\hline \multirow[t]{2}{*}{ First authorlyear } & \multirow[t]{2}{*}{$\mathbf{N}$} & \multicolumn{2}{|l|}{ Reported rates of adverse events } \\
\hline & & Ocular & Systemic \\
\hline Parrish $85 / 2003$ & 410 & $\begin{array}{l}\mathrm{CH}: \operatorname{Bim} 68.6 \% \text {, Trav 58.0\%, Lat } 47.1 \%, P=0.00 \text { I Bim vs Lat } \\
\text { Moderate } \mathrm{CH} \text { : Bim 15.3\%, Trav 10.1\%, Lat 5.9\% } \\
\text { Eye irritation: Bim 10.9\%, Trav 4.3\%, Lat } 6.6 \% \\
\text { Eyelash growth: Bim 2.9\%, Trav 0.7\%, Lat 0\% } \\
\text { Skin discoloration: Bim 2.9\%, Trav 2.9\%, Lat } 1.5 \%\end{array}$ & $\begin{array}{l}\text { Bim } 18.2 \% \text {, Trav } 16.7 \% \text {, Lat } 16.9 \% \text {. Events } \\
\text { reported }>2 \% \text { were nasopharyngitis, } \\
\text { upper respiratory tract infection, } \\
\text { headache }\end{array}$ \\
\hline DuBiner $63 / 2001$ & 43 & $\mathrm{CH}: \mathrm{Bim} 14.3 \%$, Lat $14.3 \%$ & \\
\hline Gandolfi64/200I & 232 & $\begin{array}{l}\text { CH: Bim } 36.1 \% \text {, Lat I } 4.2 \%, P \leq 0.00 \mathrm{I} \text {. Mild } \\
\text { Eyelash growth: Bim I } 2.6 \% \text {, Lat } 4.4 \%, P=0.026 \\
\text { Ant uveitis: I subject each } \\
\text { No CME or iris change }\end{array}$ & Headache: $4.4 \%$ Lat vs $0 \%$ Bim, $P=0.026$ \\
\hline Noecker ${ }^{86} / 2003$ & 269 & $\begin{array}{l}\mathrm{CH} \text { (slit-lamp): } \operatorname{Bim} 55.4 \% \text {, Lat } 42.5 \%, P<0.00 \text { I } \\
\text { Eyelash growth: } \mathrm{Bim}>\text { Lat, } P=0.064 \\
\text { Iris change: I subject Bim } \\
\text { Ant uveitis: I subject Lat } \\
\text { No CME }\end{array}$ & $\begin{array}{l}\text { I } 2 \text { serious adverse events. None reported } \\
\text { to be related to study medication }\end{array}$ \\
\hline Walters ${ }^{78} / 2004$ & 76 & $\begin{array}{l}\text { CH: Bim } 39.5 \% \text {, Lat I5.8\%, } P=0.02 \text { I. Mild I } 4 / I 5 \text { cases } \\
\text { Eye pruritis: Bim I3.2\%, Lat } 2.6 \%, P=0.20 \\
\text { Ant uveitis: I subject Lat } \\
\text { No CME }\end{array}$ & - \\
\hline Netland ${ }^{68} / 2001$ & 390 & $\begin{array}{l}\mathrm{CH}: \text { Trav } 38.0 \% \text {, Lat } 27.6 \% \text {, mainly mild } \\
\text { Eyelash growth: Trav } 57.1 \% \text {, Lat } 25.8 \% \\
\text { Iris change: Trav } 3.1 \% \text {, lat } 5.2 \% \\
\text { No anterior uveitis, No CME }\end{array}$ & - \\
\hline Cantor $^{87} / 2006$ & 157 & $\begin{array}{l}\mathrm{CH}: \text { Bim } 2 \mathrm{I} . \mathrm{I} \% \text {, Trav } 14.8 \%, P=0.326 \\
\text { Ocular itching: Bim } 2.3 \% \text {, Trav } 7.4 \%, P=0.278 \\
\text { Iris change: I subject Bim }\end{array}$ & - \\
\hline
\end{tabular}

Abbreviations: Ant, anterior; Bim, bimatoprost $0.03 \%$; $\mathrm{CH}$, conjunctival hyperemia; CME, cystoid macular edema; Lat, latanoprost $0.005 \%$; Trav, travoprost $0.004 \%$. 
Phenyl-substituted analogs significantly reduced the surface hyperemic effect of PGF2 $\alpha$ - isopropyl ester, based on reduced co-stimulation of the vasodilatory EP prostanoid receptors, although other mechanisms involving both sensory nerves and a release of nitric oxide (NO) are at play. ${ }^{22}$

\section{Iris pigmentation}

Iris darkening is a recognized, common, and significant ocular side effect of PGAs, ${ }^{73,111,214}$ and changes appear to be irreversible or very slowly reversible. ${ }^{215,216}$ Latanoprost-induced iris hyperpigmentation after 1 year was noted in $12 \%, 23 \%$, and $11 \%$ of patients in the USA, UK, and Scandinavia, respectively, mostly in mixed-color eyes (green-brown, yellowbrown, and blue/grey brown). ${ }^{68}$ Iris pigmentation change was lower in travoprost $0.004 \%(3.1 \%)$ than latanoprost $(5.2 \%){ }^{68}$ A third of subjects with hazel irides developed recognizable iris darkening by 5 years. ${ }^{215} \mathrm{~A}$ high 12-month incidence of $42.8 \% \%^{217}$ to $58.2 \%{ }^{218}$ of iris darkening in brown irides in Japan $^{214,216}$ and Taiwan ${ }^{217}$ has been documented. Homogeneous blue, green, or grey eyes are rarely affected. ${ }^{214,216}$ Iris pigmentation may appear as soon as 3 months after initiation, develop in most (75\%) affected subjects within 7 months, ${ }^{217}$ and stabilize from $12^{126}$ to 36 months. ${ }^{215}$

Increased iris hyperpigmentation is likely to be related to PGA-stimulated increase melanogenesis, ${ }^{22,219-222}$ and possible increase in iris stromal melanocyte numbers ${ }^{223}$ or their migration to the anterior border region with no net gain in melanin or melanocyte numbers. ${ }^{224}$ Latanoprost-exposed iridectomy specimens showed increased melanin within the stromal melanocytes, but no evidence of pre-malignant change. ${ }^{225}$ Tissue culture 226,227 and light microscopy ${ }^{216}$ experiments do not show division and replication of iris stromal melanocytes. In vitro increase in PGE2 by latanoprost also suggests its role as an intracellular signaling agent to promote gene transcription and melanogenesis. ${ }^{22}$ Potential problems with excess melanin include melanin granule release and inflammatory response in the stroma, melanin-induced anterior uveitis, or secondary pigment-induced glaucoma. ${ }^{228}$

\section{Hypertrichosis}

Reported increase in length, number, color and thickness of eyelashes, ${ }^{229,230}$ from all PGAs, ${ }^{64}$ can affect between $45 \%$ and $57 \%$ of subjects after 6 to 12 months' treatment, ${ }^{229,231}$ and interfere with drop instillation. ${ }^{232}$ Also, additional lash rows, conversion of vellus to terminal hairs in canthal areas and regions adjacent to lash rows, ${ }^{233}$ lash ptosis, trichiasis, reversal of alopecia and poliosis can occur. ${ }^{234,235}$ Randomized studies over 3 months found over 3 -fold increase with bimatoprost compared with latanoprost. ${ }^{64,85}$ The increased number of lashes is consistent with the ability of the PGA to induce anagen (the growth phase) in telogen (resting) follicles while inducing hypertrophic changes in the involved follicles. The increased lash length is consistent with the ability of the PGA to prolong the anagen phase of the hair cycle. Initiation and completion of PGA induced hair growth effects occur very early in anagen and the likely target is the dermal papilla. ${ }^{233}$

\section{Periocular skin pigmentation}

Darkening of the skin of the lids or other sites around the eye has been reported as a side effect associated with PGA use, ${ }^{236-242}$ including development in black ${ }^{236}$ subjects. The incidence of acquired skin pigmentation was $1.5 \%$ for latanoprost and $2.9 \%$ for bimatoprost and travoprost in one trial, ${ }^{85}$ although numbers were small, and follow-up only 12 weeks. ${ }^{85}$ Pigmentation can develop within months, and possibly earlier with bimatoprost use compared with latanoprost (1 vs 3 months), ${ }^{236}$ or take even as long as 3 years. ${ }^{238}$ Periocular pigmentation resolves without sequelae within 3 to 12 months for bimatoprost ${ }^{239}$ and weeks for latanoprost. ${ }^{236-238}$ with medication cessation. PGA-induced increase in melanogenesis ${ }^{216}$ and melanocyte proliferation ${ }^{243}$ have been implicated, ${ }^{244}$ although a contact dermatitis-like reaction with inflammation may contribute. ${ }^{239,245} \mathrm{FP}$ receptors have been localized in hair follicles. ${ }^{216}$

\section{Cystoid macular edema}

Endogenous prostaglandin release induced by anterior segment inflammation can lead to blood aqueous breakdown, inflammatory mediators reaching the macula, and cystoid macular edema (CME). Prostaglandin levels increase after cataract surgery ${ }^{246}$ and CME can resolve with non-steroidal antiinflammatory therapy (NSAID). ${ }^{247,248}$ Laser flare cell meter shows latanoprost enhances breakdown of blood-aqueous barrier and increase in angiographic CME after cataract surgery, ${ }^{249}$ although disputable. ${ }^{71-73,81,250} \mathrm{CME}$ is reported to be higher in patients with posterior capsular rupture with vitreous loss, chronic topical medication use including epinephrine ${ }^{251}$ possibly due to increased prostaglandin synthesis induced by benzalkonium chloride (BAC), ${ }^{248}$ diabetes, and following laser procedures including laser capsulotomy. ${ }^{228} \mathrm{~A}$ definitive link between PGA and CME is, however, hard to establish, as eyes developing CME generally have an independent risk factor for $\mathrm{CME} .{ }^{250}$ Pharmacologic considerations indicate that concentrations of PGA reaching the posterior segment are too low to induce vascular actions. ${ }^{250}$ 
Anecdotal reports of $\mathrm{CME}^{252-255}$ with PGA use (latanoprost, travoprost, bimatoprost or unoprostone) occurred in patients with CME risk factors including aphakia, complicated cataract surgery, ruptured PC, history of uveitis, and retinal inflammatory or vascular disease. One study found clinical CME in 2/136 eyes (1.2\%), but one subject had a ruptured posterior capsule and anterior chamber lens and the other was pseudophakic and had active uveitis 1 month prior to starting latanoprost. ${ }^{256}$ Another study found clinical CME in 3/212 (1.4\%) post-cataract eyes on latanoprost therapy, all of whom had a ruptured posterior capsule requiring vitrectomy. ${ }^{257}$ In a prospective study of latanoprost therapy in 33 pseudophakic eyes, with ruptured posterior capsules, 2 (6\%) had clinical CME. ${ }^{258}$ However, there were no cases of CME reported in Phase I and II latanoprost trials (about 800 subjects) and incidence was less than $1 \%$ in Phase III studies (about 2400 patients over 6 months). ${ }^{250}$ A study of 605 patients (excluding subjects with ocular trauma or incisional eye surgery) reported no CME with travoprost use. ${ }^{122}$ In 163 eyes of 84 consecutive patients with uveitis and raised IOP, there was no increase in the frequency of visually significant $\mathrm{CMO}(P=0.19)$ or anterior uveitis $(P=0.87)$ with PGA treatment compared with no PGA treatment. ${ }^{259}$

Although CME risk appears extremely low to non-existent in low-risk eyes (no intraocular surgery or uveitis) ${ }^{260}$ and that even high risk eyes have relatively low incidence, caution should still be exercised during use in high risk eyes. ${ }^{250} \mathrm{CME}$ is reversible with discontinuation, and preventable with a NSAID without loss of effectivity. ${ }^{249}$

\section{Anterior uveitis}

Anterior uveitis is a rare potential side effect of PGA. PGF2 $\alpha$ may stimulate the release of PGE2, and hence activate phospholipase II, enhancing the production of inflammatory eicosanoids. ${ }^{261}$ In support of an association between PGA and anterior uveitis, the inflammation appears to occur in the ipsilateral treated eye, ${ }^{261}$ improve after cessation and recur after rechallenge. ${ }^{256}$ Excessive doses may induce iritis. ${ }^{262}$ Affected subjects may have history of prior inflammation and/or incisional surgery. ${ }^{261} \mathrm{~A}$ case report ${ }^{256}$ documents an anterior uveitis rate as high as $4.9 \%$, although no increase was found in PGA-treated subjects with anterior uveitis compared with those not on PGA treatment. ${ }^{259}$ No increase in uveitic relapse rates were found when latanoprost was compared with FCDT $(P=0.21){ }^{263}$ Fluorophotometry and laser-flare cell meters have failed to detect an effect of latanoprost on aqueous flare intensity. ${ }^{170}$

\section{Herpes simplex keratitis}

Herpes simplex keratitis (HSK) associated with latanoprost use has been reported to recur with latanoprost rechallenge, be unresponsive to anti-viral therapy until latanoprost was stopped, ${ }^{264}$ and cause recurrent disease when inactive for 10 years. ${ }^{265}$ HSV type 1 infected white rabbit eyes ${ }^{266}$ had an increased severity of active HSK within 5 days of initiating topical latanoprost, and a significant increase in the clinical recurrence of HSK, although increased doses were given, and lack of viral cultures could not exclude development of pseudo-dendrites with epithelial toxicity. Data extracted from the claims records of 93,869 glaucoma patients between 1996 and 2002, showed 411 patients with ocular herpes simplex virus, which is a similar rate to that found in the general population and did not correlate with any particular antiglaucoma therapy ${ }^{267}$ The risk of activating an ocular herpes simplex infection through the initiation of PGA is thus quite low, but based on anecdotal ${ }^{264}$ and laboratory reports, it is important to enquire about history of HSK before initiating therapy.

\section{Iris cyst}

Reversible iris cyst formation is a rare reported complication of latanoprost use. ${ }^{268-271}$ Proposed mechanisms of iris cyst formation may be related to flow pressures on the ciliary muscle and intraepithelial space of the posterior iris created by increased uveoscleral drainage $\mathrm{e}^{269,272}$ in predisposed subjects, or influence on secretory functions of cyst epithelium. Rapid reversal and lack of recurrences makes any proliferative event unlikely.

\section{Systemic adverse events}

PGA related systemic adverse events occurring via nasopharyngeal mucosal absorption ${ }^{273}$ are infrequently seen due to a relatively rapid elimination half-life. Thromboxane A2, PGF2 and PGE2 elicit contractile responses in isolated human bronchial smooth muscle with bronchial hyperresponsiveness and constriction, and changes in microvascular leakage airway smooth muscle. ${ }^{273}$ PGAs are however, relatively selective PGF $2 \alpha$ receptor agonists with minimal effects on the thromboxane receptor. ${ }^{274} \mathrm{~A}$ randomized cross-over study exposing subjects with stable asthma to 6 days of latanoprost followed by a 2-week washout, found no significant effects on peak expiratory flow, asthma symptoms or requirement for asthma medications. ${ }^{273}$ Latanoprost for 3 months did not affect peak expiratory flow, forced expiratory volume in 1 second $\left(\mathrm{FEV}_{1}\right)$, and $\mathrm{FEV}_{1}$ /forced ventilatory capacity in 33 patients with newly diagnosed glaucoma. ${ }^{157}$ In a 6-month 
clinical study, adverse respiratory events were similar for latanoprost $(2 \%)$ and brimonidine $(2 \%) .{ }^{83}$ However, a Swedish study found discontinuation of latanoprost therapy ameliorated deterioration of asthma in three patients with pre-existing asthma, ${ }^{275}$ and severe apnea occurred 30 minutes after administration of latanoprost in one patient, which disappeared within 1 hour.

Upper respiratory tract infection interestingly was the most common systemic adverse event from latanoprost observed in clinical trials and occurred at a rate of approximately 4\%. ${ }^{276}$ Other systemic events included chest pain, muscle/joint/back pain, and rash/allergic skin reaction. ${ }^{276}$ Angina, ${ }^{277}$ latanoprost-induced arterial hypertension and tachycardia, ${ }^{278}$ facial and peripheral edema, and new-onset migraine $64^{279}$ have been anecdotally reported. Concurrent use of vitamin $\mathrm{E}$ in 2 subjects with arterial hypertension ${ }^{278}$ may have altered arachidonic acid metabolism, and hence prostaglandin quantities. ${ }^{278}$ Intravenous infusion of latanoprost in cynomolgus monkeys at 10 times the clinical dose had no cardiovascular or pulmonary effects. ${ }^{32}$

\section{Dosage and administration}

PGAs are indicated for the reduction of IOP in OH and OAG. All PGAs are supplied as a sterile, isotonic, buffered aqueous solution with their respective active ingredient (latanoprost $0.005 \%$ [50 $\mu \mathrm{g} / \mathrm{mL}$ ], travoprost $0.004 \%$ [40 $\mu \mathrm{g} / \mathrm{mL}$, and bimatoprost $0.03 \%[0.3 \mathrm{mg} / \mathrm{mL}]$ ) and benzalkonium chloride as the preservative. Travoprost has the lowest $\mathrm{pH}$ at 6.0 , followed by latanoprost (6.7) and bimatoprost (6.8 to 7.8). A single drop of PGA once daily in the evening is the recommended dosage. ${ }^{276}$ Increased PGA dosage frequency ${ }^{24,129,143,280,281}$ or combined PGA therapy ${ }^{282}$ can result in diminished action, possibly due to desensitization at the level of the FP receptor. ${ }^{24}$

Efficacy of eye drops is dependent on proper storage and preservation. Unopened bottles of latanoprost should be refrigerated between $2^{\circ} \mathrm{C}$ and $8^{\circ} \mathrm{C}$, whereas opened bottles can be stored at room temperatures for up to 6 weeks. Bimatoprost can be stored at temperatures between $15^{\circ} \mathrm{C}$ and $25^{\circ} \mathrm{C}$, and travoprost between $2{ }^{\circ} \mathrm{C}$ and $25^{\circ} \mathrm{C}$ for up to 6 weeks. ${ }^{281}$ If used in combination with other topical ocular hypotensive agents, the medications should be administered at least 5 minutes apart to avoid wash-out and precipitation with drops containing thimerosal. ${ }^{276}$ Contact lenses should be removed prior to instillation for 15 minutes. ${ }^{283}$ Polypropylene bottles are needed to dispense travoprost as polyethylene used for latanoprost and bimatoprost allow adherence of travoprost to the sides of the container, thus decreased concentrations. ${ }^{17}$
Contraindications include known hypersensitivity to the active or other ingredients, or benzalkonium chloride. Cautious use in patients with intraocular inflammation (eg, iritis or uveitis), renal or hepatic disease (as not investigated), pediatric patients, pregnancy (no adequate studies), and nursing mothers should be exercised.

\section{Tolerance, medication persistency and patient-focused perspectives}

The long-term side effect profile of latanoprost has been studied most, but the other currently available PGAs appear to have a similar spectrum of side effects, supporting also the notion of similar mechanisms of action. ${ }^{12}$ A large 5-year, open-label, multicenter study of latanoprost safety ${ }^{284}$ $(n=5854)$, found macular edema, iritis/uveitis, or corneal erosion rates of $\leq 2.72 \%$ and a serious adverse drug reaction (CME $(n=4)$, uveitis $(n=3)$, chest pain, eye irritation, headache, dermatitis due to eye drop allergy, conjunctivitis, dyspnea and macular degeneration $(n=1$ each)) rate of $0.44 \%$ with latanoprost use, similar to the usual care group. Overall discontinuation rates with latanoprost (2.46\%) were similar to usual care (2.24\%), and most frequently attributed to macular edema and iritis/uveitis, although unmasked groups could have led to a biased association. ${ }^{284}$ Discontinuation from respiratory disease was more frequent in the usual care group (60 vs 16 patients). ${ }^{284}$ Another open-label, 5 -year study ${ }^{215}$ of adjunctive latanoprost therapy also found marked iris pigmentary change in $19.0 \%$ and moderate in $36.3 \%$ of eyes. Most other ocular adverse events (including visual field defects, cataracts, ocular hyperemia) were mild to moderate in intensity, and occurred independent of presence of increased iris pigmentation. ${ }^{215}$

Compared with other topical ocular hypotensive medications, higher discontinuation rates were found for bimatoprost (5.3\%) than for timolol (1.7\%)123 and dorzolamide/timolol combination than for latanoprost, ${ }^{186}$ although similar for bimatoprost (3.3\%) and FCDT (3.4\%). ${ }^{132}$ Compared with latanoprost, ocular adverse effects were similar to dorzolamide. ${ }^{158}$ Ocular discomfort ${ }^{188}$ and stinging ${ }^{133}$ was greater with FCDT. Ocular hyperemia was found to be similar for brimonidine and latanoprost use in one review ${ }^{158}$ but converse in a meta-analysis. ${ }^{89}$ Serious ocular adverse events were similar between brimonidine and latanoprost; ocular inflammation $(0.7 \%$ vs $1.3 \%)$ and $\mathrm{CME}(0.3 \%$ vs $1.3 \%){ }^{89}$

Rates of non-compliance with glaucoma treatment instructions are as high as $50 \%{ }^{285}$ Persistency or maintenance of therapy, involves patient satisfaction with medication tolerability, physician satisfaction with IOP control, medication 
costs, ease of administration and patient understanding of long term medication use especially where an immediate effect is not noticed. ${ }^{212,286}$ The need for multiple medications with increasingly complex dosing regimens are real obstacles to good IOP control, ${ }^{285,287}$ and clearly once daily dosing of PGA is preferred. ${ }^{190}$

The Glaucoma Adherence and Persistence Study (GAPS) analyzed persistency of PGA monotherapy among 6271 subjects followed for $>12$ months though retrospective review of pharmacy claims. ${ }^{211}$ Eleven percent of index latanoprost $(n=4071)$ patients continuously refilled their medication throughout the course of the year, as compared to $9 \%$ of bimatoprost $(n=1199)$ patients and $5 \%$ of travoprost ( $\mathrm{n}=1001)$ subjects. Reasons for medication switch were lack of efficacy (43\%) and adverse events (19\%), especially hyperemia which accounted for $2 / 3$ of adverse effect-related switches and $27 \%$ of discontinuations. Among subjects with hyperemia, 10\% reported skipping doses due to red eyes, 30\% claimed it was a problem when seeing other people, and 7\% avoided social situations when their eyes were red.

A retrospective cohort study in 2003 of 28,741 claims records of patients on any topical ocular hypotensives found timolol prescribed most frequently (43\%), followed by latanoprost (33\%), and brimonidine (18\%). Travoprost or bimatoprost were infrequently prescribed (1\% each). Compared with latanoprost-treated patients, subjects treated with timolol, dorzolamide, travoprost, and bimatoprost were $37 \%, 41 \%, 58 \%$ and $72 \%$ respectively more likely to discontinue treatment, based on a single discontinuation event. ${ }^{286}$ At 12 months, $23 \%$ of latanoprost-treated patients and $13 \%$ of patients treated with other ocular hypotensives had neither discontinued nor changed therapy. ${ }^{286}$ No association between co-payments and persistency was found. ${ }^{286}$

It is estimated that after 5 years of treatment, nearly $40 \%$ of glaucoma patients require 2 or more different medications. ${ }^{4}$ Availability of PGA combination therapy offers the advantage of 2 classes of medication in a simplified regimen of 1 drop per day. In a survey of ophthalmologists in the European Union, 98\% of doctors believed fixed combination therapy improved patient care by better compliance and quality of life (QoL). ${ }^{288}$ Other advantages include reduced washout if two or more drops are required, and reduced exposure to corneal toxic preservatives. Chronic BAC exposure induced sub-clinical inflammation may be associated with glaucoma filtration surgery failure. ${ }^{289}$ Recently introduced, tafluprost is a fully preservative-free difluoroprostaglandin derivative of PGF2 $\alpha$. There are no published IOP-lowering efficacy rates of tafluprost compared with other topical ocular hypotensive agents as yet, but no difference between preserved and non-preserved formulations were found at 4 weeks $(P=0.96)^{290}$ and ocular hyperemia rates were similar. ${ }^{291}$ Travatan $Z^{\circledR}$ (Alcon Laboratories Inc, Forth Worth, TX) has the SofZia ${ }^{\mathrm{TM}}$ preservative system. ${ }^{292}$ TravatanZ retained equivalent efficacy as travoprost, ${ }^{293}$ and a lower nonsignificant rate of ocular hyperemia was found for BAC-free travoprost (6.4\%) than travoprost $(9.0 \%) .{ }^{293}$

Existing estimates of the indirect costs of glaucoma are likely to underestimate the impact of visual field loss on functioning and QoL. ${ }^{294}$ Self-reported difficulty in using eye drops was strongly associated with decreased QoL, using the 25-item National Eye Institute Visual Function Questionnaire (VFQ-25) and short-form Health Survey (SF-12). ${ }^{295}$ Using a non-validated questionnaire, patients showed preference for latanoprost for many systemic and ocular QoL measures compared with their previous therapy, ${ }^{296}$ also supported by studies where patients switched to latanoprost from monotherapy. ${ }^{297-299}$ A review has identified 4 major types of barriers to effective patient adherence: medication regimen, patient factors, provider factors, and situational or environmental factors. ${ }^{300}$ Interestingly, in this review, nonadherence (defined by failure to fill a prescription over the initial 12 months) was 2 times higher in subjects initially started on a single agent compared with multiple agents, ${ }^{300}$ contrary to other reports. ${ }^{190,285,287}$

\section{Place of PGA in the management of OH and OAG}

Lowering IOP is unequivocally associated with reduced rates of glaucoma and glaucoma progression as documented in several large multicenter trials including the OHTS, ${ }^{4}$ the Early Manifest Glaucoma Trial,2,301 the Collaborative Normal-Tension Glaucoma Study Group, ${ }^{3,302}$ and the Advanced Glaucoma Intervention Study. ${ }^{303}$ Reduction in IOP is readily modifiable with topical ocular hypotensive agents, and these remain first-line treatment for $\mathrm{OH}$ and $\mathrm{OAG} .{ }^{304,305}$ If the IOP is not sufficiently lowered to the estimated predefined target IOP level or if there is glaucomatous progression, then additional agents are introduced guided also by the patients concurrent health issues and medications, ability to comply, and potential impact on QoL. Surgery (laser, filtering, or cyclodestructive surgery) may be warranted if topical ocular hypotensives are ineffective.

Although timolol was prescribed most frequently, followed by latanoprost and brimonidine in a US study ${ }^{286}$ this choice may be governed by cost considerations, government or other institutional restrictions and familiarity by the 
treating ophthalmologist. ${ }^{306}$ PGA have at least equivalent if not superior efficacy over timolol and other ocular hypotensive agents, and advantages of once daily application and low risk of well-recognized life-threatening complications of $\beta$-blocker therapy such as bronchospasm, cardiac arrythmias, and exacerbation of congestive heart failure. Conjunctival hyperemia, the most common side effect of PGAs tend to be mild and reversible, but commonly encountered (up to $69 \%$ in one study with bimatoprost). ${ }^{85}$ Cosmetic side effects such as eyelash growth, peri-ocular skin discoloration and iris pigmentation also occur but to a lesser extent.

The OHTS study documented that $39.7 \%$ of glaucoma patients require 2 or more different medications after 5 years of treatment. ${ }^{4}$ Simplifying dose regimen with fixed combinations of 2 ocular hypotensive medications are preferred over concomitant administration. ${ }^{305}$ Fixed combination PGA with timolol also show superiority to monotherapy of its constituent parts and equivalence to concomitant therapy to its constituent parts. Additional benefits include enhancement of adherence, reduction of medication wash-out effect, and minimization of preservative-toxicity on the ocular surface, although they should not be prescribed for patients with sensitivity to $\beta$-blocker therapy.

In summary, PGAs are powerful topical ocular hypotensive agents available in our current $\mathrm{OH}$ and glaucoma treatment armamentarium. The three main commercially available agents, latanoprost $0.005 \%$, bimatoprost $0.03 \%$, and travoprost $0.004 \%$ may differ in pharmacology, tolerability and efficacy, but only a few meaningful differences consistently demonstrated in studies using rigorous statistical and scientific criteria exist. ${ }^{7}$ All three PGAs work primarily by the same prostanoid FP receptor although controversial. All three have fairly similar and superior effectiveness for IOP reduction than other topical hypotensive agents available. Additionally, 24-hour IOP control is better with PGAs than $\beta$-blockers. PGA have near absence of systemic side effects, although do have other commonly encountered side-effects including ocular hyperemia, iris pigmentation, eyelash growth, and peri-ocular pigmentary changes. Once daily administration and near absence of systemic side effects enhances tolerance and compliance. $\mathrm{OH}$ and $\mathrm{OAG}$ patients require lifelong treatment and follow-up care to halt progression of optic neuropathy, thus preserve remaining visual function and QoL. ${ }^{307}$

\section{Disclosure}

The authors declare no conflicts of interest.

\section{References}

1. Quigley HA, Broman AT. The number of people with glaucoma worldwide in 2010 and 2020. Br J Ophthalmol. 2006;90(3):262-267.

2. Leske MC, Heijl A, Hussein M, et al. Factors for glaucoma progression and the effect of treatment: the Early Manifest Glaucoma Treatment Trial. Arch Ophthalmol. 2003;121(1):48-56.

3. Collaborative Normal-Tension Glaucoma Study Group. Comparison of glaucomatous progression between untreated patients with normaltension glaucoma and patients with therapeutically reduced intraocular pressures. Am J Ophthalmol. 1998;126(4):487-497.

4. Kass MA, Heuer DK, Higginbotham EJ, et al. The ocular hypertension treatment study: a randomized trial determines that topical ocular hypotensive medication delays or prevents the onset of primary openangle glaucoma. Arch Ophthalmol. 2002;120(6):701-713.

5. Cantor LB. Clinical pharmacology of bimatoprost. Expert Opin Drug Metab Toxicol. 2005;1(1):151-157.

6. Singh K, Spaeth G, Zimmerman T, Minckler D. Target pressure glaucomatologists' holey grail. Ophthalmology. 2000;107(4):629-630.

7. Bean GW, Camras CB. Commercially available prostaglandin analogs for the reduction of intraocular pressure: similarities and differences. Surv Ophthalmol. 2008;53 Suppl 1:S69-S84.

8. Cantor LB. Bimatoprost: a member of a new class of agents, the prostamides for glaucoma management. Expert Opin Investig Drugs. 2001;10(4):721-731.

9. Cantor LB. An update on bimatoprost in glaucoma therapy. Expert Opin Pharmacother. 2002;3(12):1753-1762.

10. Krauss AH, Woodward DF. Update on the mechanism of action of bimatoprost: a review and discussion of new evidence. Surv Ophthalmol. 2004;49 Suppl 1:S5-S11.

11. Woodward DF, Krauss AHP, Chen J, Lai RK, Spada CS, et al. The pharmacology of bimatoprost $\left(\right.$ Lumigan $\left.^{\mathrm{TM}}\right)$. Surv Ophthamol. 2001;45 Suppl 4:S337-S345.

12. Camras CB, Sharif N, Wax M, Sternschantz J. Bimatoprost, the prodrug of a prostaglandin analogue. Br J Ophthalmol. 2008;92(6):862-863.

13. Camras CB, Toris CB, Sjoquist B, et al. Detection of the free acid of bimatoprost in aqueous humor samples from human eyes treated with bimatoprost before cataract surgery. Ophthalmology. 2004;111(12):2193-2198.

14. Sharif NA, Kelly CR, Crider JY. Human trabecular meshwork cell responses induced by bimatoprost, travoprost, unoprostone, and other FP prostaglandin receptor agonist analogues. Invest Ophthalmol Vis Sci. 2003;44(2):715-721.

15. Sharif NA, Kelly CR, Crider JY, Williams GW, Xu SX. Ocular hypotensive FP prostaglandin (PG) analogs: PG receptor subtypes binding affinities and selectivities, and agonist potencies at FP and other PG receptors in cultured cells. J Ocul Pharmacol Ther. 2003;19(6):501-515.

16. Hellberg MR, Sallee VL, McLaughlin MA, et al. Preclinical efficacy of travoprost, a potent and selective FP prostaglandin receptor agonist. J Ocul Pharmacol Ther. 2001;17(5):421-432.

17. Hellberg MR, McLaughlin MA, Sharif NA, et al. Identification and characterization of the ocular hypotensive efficacy of travoprost, a potent and selective FP prostaglandin receptor agonist, and AL-6598, a DP prostaglandin receptor agonist. Surv Ophthalmol. 2002;47 Suppl 1: S13-S33.

18. Matias I, Chen J, De Petrocellis L, et al. Prostaglandin ethanolamides (prostamides): in vitro pharmacology and metabolism. J Pharmacol Exp Ther. 2004;309(2);745-757.

19. Spada CS, Krauss AH, Woodward DF et al. Bimatoprost and prostaglandin F2 $\alpha$ selectively stimulate intracellular calcium signaling in different cat iris sphincter cells. Exp Eye Res. 2005;80(1): $135-145$.

20. Wan Z, Woodward DF, Cornell CL, et al. Bimatoprost, prostamide activity, and conventional drainage. Invest Ophthalmol Vis Sci. 2007;48(9):4107-4115.

21. Toris CB, Gabelt BT, Kaufman PL. Update on the mechanism of action of topical prostaglandins for intraocular pressure reduction. Surv Ophthalmol. 2008;53 Supp1 1:S107-S120. 
22. Stjernschantz J. Studies on ocular inflammation and development of a prostaglandin analogue for glaucoma treatment. Exp Eye Res. 2004;78(4):759-766.

23. Linden $\mathrm{C}, \mathrm{Alm} \mathrm{A}$. Effects on intraocular pressure and aqueous flow of various dose regimens of latanoprost in human eyes. Acta Ophthalmol Scand. 1997;75(4):412-415.

24. Linden C, Alm A. Latanoprost twice daily is less effective than once daily: indication of receptor subsensitivity? Curr Eye Res. 1998;17(6):567-572.

25. Brubaker RF, Schoff EO, Nau CB, et al. Effects of AGN 192024, a new ocular hypotensive agent, on aqueous dynamics. Am J Ophthalmol. 2001;131(1):19-24.

26. Christiansen GA, Nau CB, McLaren JW, Johnson DH. Mechanism of ocular hypotensive action of bimatoprost (Lumigan) in patients with ocular hypertension or glaucoma. Ophthalmology. 2004;111(9):1658-1662.

27. Dinslage S, Hueber A, Diestelhorst M, Krieglstein G. The influence of latanoprost $0.005 \%$ on aqueous humor flow and outflow facility in glaucoma patients: a double-masked placebo-controlled clinical study. Graefes Arch Clin Exp Ophthalmol. 2004;242(8):654-660.

28. Toris CB, Zhan G, Fan S, et al. Effects of travoprost on aqueous humor dynamics in patients with elevated intraocular pressure. J Glaucoma. 2007;16(2):189-195.

29. Bahler CK, Howell KG, Hann CR, Fautsch MP, Johnson DH. Prostaglandins increase trabecular meshwork outflow facility in cultured human anterior segments. Am J Ophthalmol. 2008;145(1):114-119.

30. Toris CB, Camras CB, Yablonski ME. Effects of exogenous prostaglandins on aqueous humor dynamics and blood aqueous barrier function. Surv Ophthalmol. 2008;53 Supp1 2;S69-S75.

31. Weinreb RN, Toris CB, Gabelt BT, Lindsey JD, Kaufman PL. Effects of prostaglandins on the aqueous humor outflow pathways. Surv Ophthalmol. 2002;47 Suppl 1:S53-S64.

32. Stjernschantz J, Alm A. Latanoprost as a new horizon in the medica management of glaucoma. Curr Opin Ophthalmol. 1996;7(2):11-17.

33. Shaw BR, Lindsey JD, Weinreb RN: Prostaglandin release in a perfused human anterior segment model. J Glaucoma.1993;2(1):39-43.

34. Lim KS, Nau CB, O’Byrne MM, et al. Mechanism of action of bimatoprost, latanoprost, and travoprost in healthy subjects. A crossover study. Ophthalmology. 2008;115(5):790-795.

35. Oh DJ, Martin JL, Williams AJ, et al. Effect of latanoprost on the expression of matrix metalloproteinases and their tissue inhibitors in human trabecular meshwork cells. Invest Ophthalmol Vis Sci. 2006;47(9):3887-3895.

36. Gaton DD, Sagara T, Lindsey JD, et al. Increased matrix metalloproteinases 1,2 , and 3 in the monkey uveoscleral outflow pathway after topical prostaglandin F (2 alpha)- isopropyl ester treatment. Arch Ophthalmol. 2001;119(8):1165-1170.

37. Nilsson SF, Drecoll E, Lutjen-Drecoll E, et al. The prostanoid EP2 receptor agonist butaprost increases uveoscleral outflow in the cynomolgus monkey. Invest Ophthalmol Vis Sci. 2006;47(9):4042-4049.

38. Richter M, Krauss AH, Woodward DF, Lutjen-Drecoll E. Morphological changes in the anterior eye segment after long-term treatment with different receptor selective prostaglandin agonists and a prostamide. Invest Ophthalmol Vis Sci. 2003;44(10):4419-4426.

39. Mishima HK, Kiuchi Y, Takamatsu M, Racz P, Bito LZ. Circadian intraocular pressure management with latanoprost: diurnal and nocturnal intraocular pressure reduction and increased uveoscleral outflow. Surv Ophthalmol. 1997;41 Supp1 2:S139-S144.

40. Brubaker RF. Mechanism of action of bimatoprost (Lumigan ${ }^{\mathrm{TM}}$ ). Surv Ophthalmol. 2001;45 Suppl 4: S347-S351.

41. Konstas AG, Katsimbris JM, Lallos N, et al. Latanoprost $0.005 \%$ versus bimatoprost $0.03 \%$ in primary open-angle glaucoma patients. Ophthalmology. 2005;112(2):262-266.

42. Orzalesi N, Rossetti L, Bottoli A, Fogagnolo P. Comparison of the effects of latanoprost, travoprost, and bimatoprost on circadian intraocular pressure in patients with glaucoma or ocular hypertension. Ophthalmology. 2006;113(2):239-246.
43. Orzalesi N, Rossetti L, Bottoli A, Fumagalli E, Fogagnolo P. The effect of latanoprost, brimonidine, and a fixed combination of timolol and dorzolamide on circadian intraocular pressure in patients with glaucoma or ocular hypertension. Arch Ophthalmol. 2003;121(4):453-457.

44. Quaranta L, Pizzolante T, Riva I, et al. Twenty-four hour intraocular pressure and blood pressure levels with bimatoprost versus latanoprost in patients with normal-tension glaucoma. $\mathrm{Br} J$ Ophthalmol. 2008;92(9):1227-1231.

45. Yildrim N, Sahin A, Gultekin S. The effect of latanoprost, bimatoprost, and travoprost on circadian variation of intraocular pressure in patients with open-angle glaucoma. J Glaucoma. 2008;17(1):36-39.

46. Larsson LI. Intraocular pressure over 24 hours after repeated administration of latanoprost $0.005 \%$ or timolol gel-forming solution $0.5 \%$ in patients with ocular hypertension. Ophthalmology. 2001;108(8):1439-1444.

47. Reiss GR, Lee DA, Topper J, Brubaker RF. Aqueous humor flow during sleep. Invest Ophthalmol Vis Sci. 1984;25(6):776-778.

48. Geyer O, Man O, Weintraub M, Silver DM. Acute effect of latanoprost on pulsatile ocular blood flow in normal eyes. Am J Ophthalmol. 2001;131(2):198-202.

49. Sponsel WE, Mensah J, Kiel JW, et al. Effects of latanoprost and timolol-XE on hydrodynamics in the normal eye. Am J Ophthalmol. 2000;130(2):151-159.

50. Janulevicienë I, Harris A, Kagemann L, Siesky B, McCranor L. A comparison of the effects of dorzolamide/timolol fixed combination versus latanoprost on intraocular pressure and pulsatile ocular blood flow in primary open-angle glaucoma patients. Acta Ophthalmol Scand. 2004;82(6):730-737.

51. Vetrugno M, Cantatore F, Gigante G, Cardia L. Latanoprost $0.005 \%$ in POAG: effects on IOP and ocular blood flow. Acta Ophthalmol Scand Suppl. 1998;227:40-41.

52. Liu CJ, Ko YC, Cheng CY, et al. Effect of latanoprost $0.005 \%$ and brimonidine tartrate $0.2 \%$ on pulsatile ocular blood flow in normal tension glaucoma. Br J Ophthalmol. 2002;86(11):1236-1239.

53. Liu CJ, Ko YC, Cheng CY, et al. Changes in intraocular pressure and ocular perfusion pressure after latanoprost $0.005 \%$ or brimonidine tartrate $0.2 \%$ in normal-tension glaucoma patients. Ophthalmology. 2002;109(12):2241-2247.

54. McKibbin M, Menage MJ. The effect of once-daily latanoprost on intraocular pressure and pulsatile ocular blood flow in normal tension glaucoma. Eye. 1999;13(Pt 1):31-34.

55. Rolle T, Cipullo D, Vizzeri GM, et al. Evaluation and comparison between the effects on intraocular pressure and retinal blood flow of two anti-glaucomatous drugs administered in monotherapy: brimonidine and latanoprost. Preliminary results. Acta Ophthalmol Scand Suppl. 2000;78(232):50-52.

56. Drance SM, Crichton A, Mills RP. Comparison of the effect of latanoprost $0.005 \%$ and timolol $0.5 \%$ on the calculated ocular perfusion in patients with normal-tension glaucoma. Am J Ophthalmol. 1998;125(5):585-592.

57. Koz OG, Ozsoy A, Yarangumeli A, Kose SK, Kural G. Comparison of the effects of travoprost, latanoprost and bimatoprost on ocular circulation: a 6-month clinical trial. Acta Ophthalmol Scand. 2007;85(8):838-843.

58. Alagoz G, Gurel K, Bayer A, et al. A comparative study of bimatoprost and travoprost: effect on intraocular pressure and ocular circulation in newly diagnosed glaucoma patients. Ophthalmologica. 2008;222(2):88-95

59. Inan UU, Ermis SS, Yucel A, et al. The effects of latanoprost and brimonidine on blood flow velocity of the retrobulbar vessels: A 3-month clinical trial. Acta Ophthalmol Scand. 2003;81(2):155-160

60. Martínez A, Sánchez M. A comparison of the effects of $0.005 \%$ latanoprost and fixed combination dorzolamide/timolol on retrobulbar haemodynamics in previously untreated glaucoma patients. Curr Med Res Opin. 2006;22(1):67-73.

61. Nicolela MT, Buckley AR, Walman BE, Drance SM. A comparative study of the effects of timolol and latanoprost on blood flow velocity of the retrobulbar vessels. Am J Ophthalmol. 1996;122(6):784-789. 
62. Sjöquist B, Stjernschantz J. Ocular and systemic pharmacokinetics of latanoprost in humans. Surv Ophthalmol. 2002;47 Suppl 1:S6-S12.

63. DuBiner H, Cooke D, Dirks M, et al. Efficacy and safety of bimatoprost in patients with elevated intraocular pressure: a 30-day comparison with latanoprost. Surv Ophthalmol. 2001;45 Suppl 4:S353-S360.

64. Gandolfi S, Simmons ST, Sturm R, Chen K. Three-month comparison of bimatoprost and latanoprost in patients with glaucoma and ocular hypertension. Adv Ther. 2001;18(3);110-121.

65. Konstas AG, Maltezos AC, Gandi S, Hudgins AC, Stewart WC. Comparison of 24-hour intraocular pressure reduction with two dosing regimens of latanoprost and timolol maleate in patients with primary open-angle glaucoma. Am J Ophthalmol. 1999;128(1):15-20.

66. Orzalesi N, Rossetti L, Invernizzi T, et al. Effect of timolol, latanoprost, and dorzolamide on circadian IOP in glaucoma or ocular hypertension. Invest Ophthalmol Vis Sci. 2000;41(9):2566-2573.

67. Bron AM, Denis P, Nordmann JP, et al. Additive IOP-reducing effect of latanoprost in patients insufficiently controlled on timolol. Acta Ophthalmol Scand. 2001;79(3):289-293.

68. Netland PA, Landry T, Sullivan EK, et al. Travoprost compared with latanoprost and timolol in patients with open-angle glaucoma or ocular hypertension. Am J Ophthalmol. 2001;132(4):472-484.

69. Patel SS, Spencer CM. Latanoprost. A review of its pharmacological properties, clinical efficacy and tolerability in the management of primary open-angle glaucoma and ocular hypertension. Drugs Aging. 1996;9(5)363-378.

70. Camras CB, Sheu WP. United States Latanoprost-Brimonidine Study group. Latanoprost or brimonidine as treatment of elevated intraocular pressure: a multicenter trial in the United States. J Glaucoma. 2005;14(2):161-167.

71. Alm A, Stjernschantz J. Effects on intraocular pressure and side effects of $0.005 \%$ latanoprost applied once daily, evening or morning: a comparison with timolol. Scandinavian Latanoprost Study Group. Ophthalmology. 1995;102(12):1743-1752.

72. Watson P, Stjernschantz J. A six-month, randomized, double-masked study comparing latanoprost with timolol in open-angle glaucoma and ocular hypertension. The Latanoprost Study Group. Ophthalmology. 1996;103(1):126-137.

73. Camras CB. Comparison of latanoprost and timolol in patients with ocular hypertension and glaucoma: a six month masked, multicenter trial in the United States. The United States Latanoprost Study Group. Ophthalmology. 1996;103(1):138-147.

74. Aung T, Chew PT, Yip CC, et al. A randomized double-masked crossover study comparing latanoprost $0.005 \%$ with unoprostone $0.12 \%$ in patients with primary open angle glaucoma and ocular hypertension. Am J Ophthalmol. 2001;131(5):636-642.

75. O'Donoghue EP. A comparison of latanoprost and dorzolamide in patients with glaucoma and ocular hypertension: A 3 month randomized study. Ireland Latanoprost Study Group. $\mathrm{Br}$ J Ophthalmol. 2000;84(6):579-582.

76. DuBiner HB, Mroz M, Shapiro AM, Dirks MS. Brimonidine vs Latanoprost Study Group. A comparison of the efficacy and tolerability of brimonidine and latanoprost in adults with open-angle glaucoma or ocular hypertension: a three-month, multi-center, randomized, double-masked, parallel-group trial. Clin Ther. 2001;23(12): 1969-1983.

77. Stewart WC, Day DG, Stewart JA, Schuhr J, Latham KE. The efficacy and safety of latanoprost $0.005 \%$ once daily versus brimonidine $0.2 \%$ twice daily in open-angle glaucoma or ocular hypertension. Am J Ophthalmol. 2001;131(5):631-635.

78. Walters TR, DuBiner HB, Carpenter SP, Khan B, VanDenburgh AM. Bimatoprost Circadian IOP Study Group: 24-hour IOP control with once-daily bimatoprost, timolol gel-forming solution, or latanoprost: a 1-month, randomized, comparative clinical trial. Surv Ophthalmol. 2004;49 Suppl 1:S26-S35.

79. Saito M, Takano R, Shirato S. Effects of latanoprost and unoprostone when used alone or in combination for open-angle glaucoma. Am J Ophthalmol. 2001;132(4):485-489.
80. Susanna R, Giampani J, Borges AS, Vessani RM, Jordao ML. A double-masked, randomized clinical trial comparing latanoprost with unoprostone in patients with open-angle glaucoma or ocular hypertension. Ophthalmology. 2001;108(2):259-263.

81. Mishima H, Masuda K, Kitazawa Y, Azuma I, Araie M. A comparison of latanoprost and timolol in primary open-angle glaucoma and ocular hypertension: a 12-week study. Arch Ophthalmol. 1996;114(8) : 929-932.

82. Jampel HD, Bachararch J, Sheu WP, et al. The Latanoprost/Unoprostone Study Group. Randomised clinical trial of latanoprost and unoprostone in patients with elevated intraocular pressure. Am J Ophthalmol. 2002;134(6):863-871.

83. Kampik A, Arias-Puente A, O'Brart DP, Vuori ML. European Latanoprost Study Group. Intraocular pressure-lowering effects of latanoprost and brimonidine therapy inpatients with open-angle glaucoma or ocular hypertension: a randomized observer-masked multicenter study. J Glaucoma. 2002;11(2):90-96.

84. van der Valk R, Webers CA, Schouten JS, et al. Intraocular pressurelowering effects of all commonly used glaucoma drugs: a meta-analysis of randomized clinical trials. Ophthalmology. 2005;112(7):1177-1185.

85. Parrish RK, Palmberg P, Sheu WP. The XLT Study Group. A comparison of latanoprost, bimatoprost, and travoprost in patients with elevated intraocular pressure: a 12-week, randomized, masked-evaluator multicenter study. Am J Ophthalmol. 2003;135(5):688-703.

86. Noecker RS, Dirks MS, Choplin NT, et al. Bimatoprost/Latanoprost Study Group. A six-month randomized clinical trial comparing the intraocular pressure-lowering efficacy of bimatoprost and latanoprost inpatients with ocular hypertension or glaucoma. Am J Ophthalmol. 2003;135(1):55-63.

87. Cantor LB, Hoop JS, Morgan L, WuDunn D, Catoira Y. The Bimatoprost-Travoprost Study Group. Intraocular pressure-lowering efficacy of bimatoprost $0.03 \%$ and travoprost $0.004 \%$ in patients with glaucoma or ocular hypertension. Br J Ophthalmol. 2006;90(11):1370-1373.

88. Aptel F, Cucherat M, Denis P. Efficacy and tolerability of prostaglandin analogs. A meta-analysis of randomized controlled clinical trials. J Glaucoma. 2008;17(8):667-673.

89. Cheng JW, Wei RL. Meta-analysis of 13 randomised controlled trials comparing bimatoprost with latanoprost inpatients with elevated intraocular pressure. Clin Ther. 2008;30(4):622-632.

90. Eyawo O, Nachega J, Lefebvre P, et al. Efficacy and safety of prostaglandin analogues in patients with predominantly primary open-angle glaucoma or ocular hypertension: a meta-analysis. Clin Ophthalmol. 2009;3:447-456.

91. Denis P, Lafuma A, Khoshnood B, Mimaud V, Berdeaux G. A metaanalysis of topical prostaglandin analogues intra-ocular pressure lowering in glaucoma therapy. Curr Med Res Opin. 2007;23(3):601-608

92. Cantor LB, WuDunn D, Cortes A, Hoop J, Knotts S. Ocular hypotensive efficacy of bimatoprost $0.03 \%$ and travoprost $0.004 \%$ in patients with glaucoma or ocular hypertension. Surv Ophthalmol. 2004;49 Suppl 1: S12-S18.

93. Cellini M, Caramazza R, Bonsanto D, et al. Prostaglandin analogs and blood-aqueous barrier integrity: a flare cell meter study. Ophthalmologica. 2004;218(5):312-317.

94. Jin X, Qian S, Sun X. Efficacy and safety of bimatoprost $0.03 \%$ in patients with elevated intraocularpressure: A comparison with latanorpost 0.005\% [in Chinese]. Zhong-Guo Shiyong Yan Ke Za Zhi. 2005;23: $712-714$.

95. Arcieri ES, Santana A, Rocha FN, Guapo GL, Costa VP. Blood-aqueous barrier changes after the use of prostaglandin analogues in patients with pseudophakia and aphakia: a 6-month randomized trial. Arch Ophthalmol. 2005;123(2):186-192.

96. Hepsen IF, Ozkaya E. 24-h IOP control with latanoprost, travoprost, and bimatoprost in subjects with exfoliation syndrome and ocular hypertension. Eye. 2007;21(4):453-458.

97. Konstas AG, Holló G, Irkec M, et al. Diurnal IOP control with bimatoprost versus latanoprost in exfoliative glaucoma: a crossover, observermasked, three-centre study. Br J Ophthalmol. 2007;91(6):757-760. 
98. Cardascia N, Vetrugno M, Trabucco T, et al. Effects of travoprost eye drops on intraocular pressure and pulsatile ocular blood flow: a 180-day, randomized, double masked comparison with latanoprost eye drops in patients with open-angle glaucoma. Curr Ther Res Clin Exp. 2003;64:389-400.

99. Parmaksiz S, Yuksel N, Karabas VL, et al. A comparison of travoprost, latanoprost, and the fixed combination of dorzolamide and timolol in patients with pseudoexfoliation glaucoma. Eur J Ophthalmol. 2006;16(1):73-80.

100. Topouzis F, Melamed S, Danesh-Meyer H, et al. A 1-year study to compare the efficacy and safety of once-daily travoprost $0.004 \%$ / timolol $0.5 \%$ to once-daily latanoprost $0.005 \% /$ timolol $0.5 \%$ inpatients with open-angle glaucoma or ocular hypertension. Eur J Ophthalmol. 2007; 17(2):183-190.

101. Noecker RJ, Earl ML, MundorfT, Peace J, Williams RD. Bimatoprost $0.03 \%$ versus travoprost $0.004 \%$ in black Americans with glaucoma or ocular hypertension. Adv Ther. 2003;20(2):121-128.

102. Noecker RJ, Earl ML, Mundorf TK, Silverstein SM, Phillips MP. Comparing bimatoprost and travoprost in black Americans. Curr Med Res Opin. 2006;22(11):2175-2180.

103. Dirks MS, Noecker RJ, Earl M, et al. A 3-month clinical trial comparing the IOP-lowering efficacy of bimatoprost and latanoprost in patients with normal-tension glaucoma. Adv Ther. 2006;23(3):385-94.

104. Dubiner HB, Sircy MD, Landry T, et al. Comparison of the diurnal ocular hypotensive efficacy of travoprost and latanoprost over a 44-hour period in patients with elevated intraocular pressure. Clin Ther. 2004;26(1):84-91.

105. Li N, Chen XM, Zhou Y, Wei ML, Yao X. Travoprost compared with other prostaglandin analogues or timolol in patients with open-angle glaucoma or ocular hypertension: meta-analysis of randomized controlled trials. Clin Exp Ophthalmol. 2006;34(8):755-764.

106. Hedman K, Alm A. A pooled-data analysis of three randomized, double-masked, six-month clinical studies comparing the intraocular pressure reducing effect of latanoprost and timolol. Eur J Ophthalmol. 2000;10(2):95-104.

107. Alm A, Camras CB, Watson PG. Phase III Latanoprost studies in Scandinavia, the United Kingdom and the United States. Surv Ophthalmol. 1997;41 Suppl 2: S105-S110.

108. Hedman K, Watson PG, Alm A. The effect of latanoprost on intraocular pressure during 2 years of treatment. Surv Ophthalmol. 2002;47 Suppl 1: S65-S76.

109. Suzuki M, Mishima HK, Masuda K, et al. Efficacy and safety of latanoprost eye drops for glaucoma treatment: a 1-year study in Japan. Jpn J Ophthalmol. 2000;44(1):33-38.

110. Alm A, Widengard I. Latanoprost: experience of 2-year treatment in Scandinavia. Acta Ophthalmol Scand. 2000;78(1):71-76.

111. Watson PG. Latanoprost. Two years' experience of its use in the United Kingdom. Latanoprost Study Group. Ophthalmology. 1998;105(1): $82-87$.

112. Camras CB, Alm A, Watson P, Stjernschantz J. Latanoprost, a prostaglandin analog, for glaucoma therapy: efficacy and safety after 1 year of treatment in 198 patients. Latanoprost Study Groups. Ophthalmology. 1996;103(11):1916-1924.

113. Hedman K, Larsson L. The effect of latanoprost compared with timolol in African-American, Asian, Caucasian, and Mexican open-angle glaucoma or ocular hypertensive patients. Surv Ophthalmol. 2002;47 Suppl 10:S77-S89.

114. Costagliola C, Del Prete A, Verolino MM, et al. Effect of $0.005 \%$ latanoprost once daily on intraocular pressure in glaucomatous patients not adequately controlled by beta-blockers twice daily: a three year follow-up. Experience and incidence of side effects in a prospective study on 76 patients. Graefes Arch Clin Exp Ophthalmol. 2002;240(5):379-386.

115. Zhang WY, Li Wan Po A, Dua HS, Azuara-Blanco A. Meta-analysis of randomized controlled trials comparing latanoprost with timolol in the treatment of patients with open-angle glaucoma or ocular hypertension. Br J Ophthalmol. 2001;85(8):983-990.
116. Aquino MV, Lat-Luna M. The effect of latanoprost vs timolol on intraocular pressure in patients with glaucoma and ocular hypertension. Asian J Ophthalmol. 1999;1(3):3-7.

117. Diestelhorst M, Almegard B. Comparison of two fixed combinations of latanoprost and timolol in open-angle glaucoma. Graefes Arch Clin Exp Ophthalmol. 1998;236(8):577-581.

118. Diestelhorst M, Roters S, Krieglstein GK. The effect of latanoprost $0.005 \%$ once daily versus $0.0015 \%$ twice daily on intraocular pressure and aqueous humor protein concentration in glaucoma patients. A randomized, double - masked comparison with timolol 0.5\% Graefes Arch Clin Exp Ophthalmol. 1997;235(1):20-26.

119. Mastropasqua L, Carpineto P, Ciancaglini M, Gallenga PE. A 12-month, randomized, double-masked study comparing latanoprost with timolol in pigmentary glaucoma. Ophthalmology. 1999;106(3):550-555.

120. Rulo AH, Greve EL, Hoyng PF. Additive effect of latanoprost, a prostaglandin F2 $\alpha$ analogue, and timolol in patients with elevated intraocular pressure. Br J Ophthalmol. 1994;78(12):899-902.

121. Goldberg I, Cunha-Vaz J, Jakobsen JE, et al. International Travoprost Study Group. Comparison of topical travoprost eye drops given once daily and timolol $0.5 \%$ given twice daily in patients with open-angle glaucoma or ocular hypertension. J Glaucoma. 2001;10(5):414-422.

122. Fellman RL, Sullivan EK, Ratliff M, et al. Comparison of travoprost $0.0015 \%$ and $0.004 \%$ with timolol $0.5 \%$ in patients with elevated intraocular pressure: a 6-month, masked, multicenter trial. Ophthalmology. 2002;109(5):998-1008.

123. Higginbotham EJ, Schuman JS, Goldberg IM, et al. The Bimatoprost Study Groups 1 and 2. One-year, randomized study comparing bimatoprost and timolol in glaucoma and ocular hypertension. Arch Ophthalmol. 2002;120(10):1286-1293.

124. Brandt JD, VanDenburgh AM, Chen K, Whitcup SM. Bimatoprost Study Group 1. Comparison of once- or twice-daily bimatoprost with twice daily timolol in patients with elevated IOP: a 3 month clinical trial. Ophthalmology. 2001;108(6):1023-1031.

125. Whitcup SM, Cantor LB, VanDenburgh AM, Chen K. A randomized, double-masked, multicentre clinical trial comparing bimatoprost and timolol for the treatment of glaucoma and ocular hypertension. $\mathrm{Br} J$ Ophthalmol. 2003;87(1):57-62.

126. Cohen JS, Gross RL, Cheetham JK, et al. Two-year double-masked comparison of bimatoprost with timolol in patients with glaucoma or ocular hypertension. Surv Ophthalmol. 2004;49 Suppl 1:S45-S52.

127. Williams RD, Cohen JS, Gross RL, et al. Long-term efficacy and safety of bimatoprost for intraocular pressure lowering in glaucoma and ocular hypertension: year 4. Br J Ophthalmol. 2008;92(10):1387-1392.

128. Holmstrom S, Buchholz P, Walt J, Wickstrom J, Aagren M. Analytic review of bimatoprost, latanoprost and travoprost in primary open angle glaucoma. Curr Med Res Opin. 2005;21(11):1875-1883.

129. Alm A, Villumsen J, Tornquist $P$, et al. Intraocular pressure-reducing effect of PhXA41 inpatients with increased eye pressure. A one-month study. Ophthalmology. 1993;100(9):1312-1317.

130. Bucci MG. Intraocular pressure-lowering effects of latanoprost monotherapy versus latanoprost or pilocarpine in combination with timolol: a randomized, observer-masked multicenter study in patients with open-angle glaucoma. Italian Latanoprost Study Group. J Glaucoma. 1999;8(1):24-30.

131. Chew PTK, Hung PT, Aung T. Efficacy of latanoprost inreducing intraocular pressure in patients with primary angle-closure glaucoma. Surv Ophthalmol. 2002;47 Suppl 1:S125-S128.

132. Coleman AL, Lerner F, Bernstein P, Whitcup SM. A 3-month randomized controlled trial of bimatoprost(LUMIGAN)versus combined timolol and dorzolamide(Cosopt)in patients with glaucoma or ocular hypertension. Ophthalmology. 2003;110(12):2362-2368.

133. Fechtner RD, Airaksinen PJ, Getson AJ, Lines CR, Adamsons IA. Efficacy and tolerability of the dorzolamide $2 \% /$ timolol $0.5 \%$ combination (COSOPT) versus $0.005 \%$ (XALATAN) in the treatment of ocular hypertension or glaucoma: results from two randomized clinical trials. COSOPT versus XALATAN Study Groups. Acta Ophthalmol Scand. 2004;82(1):42-48. 
134. Toris CB, Camras CB, Yablonski ME. Effects of PhXA41, a new prostaglandin F2 alpha analog, on aqueous humor dynamics in human eyes. Ophthalmology. 1993;100(9):1297-1304.

135. Thygesen J, Aaen K, Theodorsen F, Kessing SV, Prause JU. Short-term effect of latanoprost and timolol eye drops on tear fluid and the ocular surface in patients with primary open-angle glaucoma and ocular hypertension. Acta Ophthalmol Scand. 2000;78(1):37-44.

136. Gandolfi SA, Cimino L. Effect of bimatoprost on patients with primary open-angle glaucoma or ocular hypertension who are nonresponders to latanoprost. Ophthalmology. 2003;110(3):609-614.

137. Higginbotham EJ, Feldman R, Stiles M, Dubiner H. Fixed Combination Investigative Group. Latanoprost and timolol combination therapy vs monotherapy: one-year randomized trial. Arch Ophthalmol. 2002;120(7):915-922.

138. Kjellgren D, Douglas G, Mickelberg FS, Drance SM, Alm A. The short-time effect of latanoprost on the intraocular pressure in normal pressure glaucoma. Acta Ophthalmol Scand. 1995;73(3):233-236.

139. Laibovitx RA, VanDenburgh AM, Felix C, et al. Comparison of the ocular hypotensive lipid AGN 192024 with timolol: dosing, efficacy, and safety evaluation of a novel compound for glaucoma management. Arch Ophthalmol. 2001;119(7):994-1000.

140. Manni G, Centofanti M, Parravano M, Oddone F, Bucci MG. A 6-month randomized clinical trial of bimatoprost $0.03 \%$ versus the association of timolol $0.5 \%$ and latanoprost $0.005 \%$ in glaucomatous patients. Graefes Arch Clin Exp Ophthalmol. 2004;242(9): 767-770.

141. Nordmann JP, Soderstrom M, Rouland JF, Malecaze F. Comparison of the intraocular pressure lowering effect of latanoprost and a fixed combination of timolol-pilocarpine eye drops in patients insufficiently controlled with $\beta$-adrenergic antagonists. French latanoprost study Group and the Swedish Latanoprost Study Group. Br J Ophthalmol. 2000;84(2):181-185.

142. Pfeiffer N. European Latanoprost Fixed Combination Study Group. A comparison of the fixed-combination of latanoprost and timolol with its individual components. Graefe's Arch Clin Exp Ophthalmol. 2002;240(11):893-899.

143. Sherwood M, Brandt J; Bimatoprost Study Groups 1 and 2. Six-month comparison of bimatoprost once-daily and twice-daily with timolol twice-daily in patients with elevated intraocular pressure. Surv Ophthalmol. 2001;45 Suppl 4:S361-S368.

144. Barnebey HS, Orengo-Nania S, Flowers BE, et al. The safety and efficacy of travoprost $0.004 \%$ /timolol $0.5 \%$ fixed combination ophthalmic solution. Am J Ophthalmol. 2005;140(1):1-7.

145. Einarson TR, Kulin NA, Tingey D, Iskedjian M. Meta-analysis of the effect of latanoprost and brimonidine on intraocular pressure in the treatment of glaucoma. ClinTher. 2000;22(12):1502-1515.

146. Fung AT, Reid SE, Jones MP, et al. Meta-analysis of randomised controlled trials comparing latanoprost with brimonidine in the treatment of open-angle glaucoma, ocular hypertension or normal-tension glaucoma. Br J Ophthalmol. 2007;91(1):62-68.

147. LeBlanc RP. Twelve-month results of an ongoing randomized trial comparing brimonidine tartrate $0.2 \%$ and timolol $0.5 \%$ given twice daily in patients with glaucoma or ocular hypertension. Brimonidine Study Group 2. Ophthalmology. 1998;105(10):1960-1967.

148. Schuman JS, Horwitz B, Choplin NT, et al. A 1-year study of brimonidine twice daily in glaucoma and ocular hypertension. A controlled, randomized, multicentre clinical trial. Chronic Brimonidine Study Group. Arch Ophthalmol. 1997;115(7):847-852.

149. Serle JB. A comparison of the safety and efficacy of twice daily brimonidine $0.2 \%$ versus betaxolol $0.25 \%$ in subjects with elevated intraocular pressure. The Brimonidine Study Group III. Surv Ophthalmol. 1996;41 Suppl 1: S39-S47.

150. Akman A, Cetinkaya A, Akova YA, et al. Comparison of additional intraocular pressure-lowering effects of latanoprost vs brimonidine in primary open-angle glaucoma patients with intraocular pressure uncontrolled by timolol-dorzolamide combination. Eye. 2005;19(2): $145-151$.
151. Simmons ST, Earl ML. Three-month comparison of brimonidine and latanoprost as adjunctive therapy in glaucoma and ocular hypertension patients controlled on $\beta$-blockers: tolerance and peak intraocular pressure lowering. Alphagan/Xalatan Study Group. Ophthalmology. 2002;109(2):307-314.

152. Simmons ST, Samuelson TW. Comparison of brimonidine with latanoprost in the adjunctive treatment of glaucoma. ALPHAGAN/ XALATAN study group. Clin Ther. 2000;22(4):388-399.

153. Sodhi PK, Pandey RM, Ratan SK. Efficacy and safety of brimonidine, dorzolamide and latanoprost as adjunctive therapy in primary open angle glaucoma. Int J Clin Pract. 2003;57(10):875-878.

154. Stewart WC, Stewart JA, Day D, Sharpe ED. Efficacy and safety of timolol maleate. Latanoprost fixed combination versus timolol maleate and brimonidine given twice daily. Acta Ophthalmol Scand. 2003;81(3):242-246.

155. De Figueiredo CR, De Figueiredo BP. Ocular blood flow in topical eye hypotensive medication: prospective study (in Portugese). Rev Bras Oftalmol. 2001;60:471-476.

156. Garcia-Sanchez J, Rouland JF, Spiegel D, et al. A comparison of the fixed combination of latanoprost and timolol with the unfixed combination of brimonidine and timolol in patients with elevated intraocular pressure. A six month, evaluator masked, multicenter study in Europe. Br J Ophthalmol. 2004;88(7):877-883.

157. Waldock A, Snape J, Graham CM. Effects of glaucoma medications on the cardiorespiratory and intraocular pressure status of newly diagnoses glaucoma patients. Br J Ophthalmol. 2000;84(7):710-713.

158. Hodge WG, Lachaine J, Steffensen I, et al. The efficacy and harm of prostaglandin analogues for IOP reduction in glaucoma patients compared to dorzolamide and brimonidine: a systematic review. $\mathrm{Br} J$ Ophthalmol. 2008;92(1):7-12.

159. Lone AI, Rizvi A, Sajjad AS, et al. Comparison of latanoprost and dorzolamide in patients with open angle glaucoma. JK Science. 2003;5:26-28.

160. Niazi Mk, Raja N. Comparison of latanoprost and dorzolamide in the treatment of patients with open angle glaucoma. J Ayub Med Coll Abbottabad. 2004;16(1):50-53.

161. van der Valk R, Webers CA, Lumley T, et al. A network meta-analysis combined direct and indirect comparisons between glaucoma drugs to rank effectiveness in lowering intraocular pressure. J Clin Epidemiol. 2009;62(12):1279-1283.

162. Stewart WC, Konstas AG, Nelson LA, Kruft B. Meta-analysis of 24-hour intraocular pressure studies evaluating the efficacy of glaucoma medicines. Ophthalmology. 2008;115(7):1117-1122.

163. Asrani S, Zeimer R, Wilensky J, et al. Large diurnal fluctuation in intraocular pressure are an independent risk factor in patients with glaucoma. J Glaucoma. 2000;9(2):134-142.

164. Stewart WC, Day DG, Jenkins JN, Passmore CL, Stewart JA. Mean intraocular pressure and progression based oncorneal thickness in primary open-angle glaucoma. J Ocul Pharmacol Ther. 2006;22(1):26-33.

165. Jonas JB, Budde W, Stroux A, Oberacher-Velten IM, Junemann A. Single intraocular pressure measurements and diurnal intraocular pressure profiles. Am J Ophthalmol. 2005;139(6):1136-1137.

166. Barkana Y, Anis S, Liebmann J, Tello C, Ritch R. Clinical utility of intraocular pressure monitoring outside of normal office hours in patients with glaucoma. Arch Ophthalmol. 2006;124(6):793-797.

167. Costagliola C, Parmeggiani F, Virgili G, et al. Circadian changes of intraocular pressure and ocular prefusion pressure after timolol or latanoprost in Caucasians with normal-tension glaucoma. Graefes Arch Clin Exp Ophthalmol. 2008;246(3):389-396.

168. Cheng J, Cai J, Wei R. Meta-analysis of medical intervention for normal tension glaucoma. Ophthalmology. 2009;116(7):1243-1249.

169. Harris A, Migliardi R, Rechtman E, et al. Comaprative analysis of the effects of dorzolamide and latanoprost on ocular haemodynamics in normal tension glaucoma patients. Eur J Ophthalmol. 2003;13(1):24-31.

170. Kiuchi T, Motoyama Y, Oshika T. Influence of ocular hypotensive eyedrops on intraocular pressure fluctuation with postural change in eyes with normal-tension glaucoma. Am J Ophthalmol. 2007;143(4): 693-695. 
171. Rulo AH, Greve EL, Geijssen HC, et al. Reduction of introaocular pressure with treatment of latanoprost once daily in patients with normal-pressure glaucoma. Ophthalmology. 1996;103(8):1276-1282.

172. Tomita G, Araie M, Kitazawa Y, et al. A three-year prospective, randomized and open comparison between latanoprost and timolol in Japanese normal-tension glaucoma patients. Eye. 2004;18(10): 984-949.

173. Zeitz O, Matthiessen ET, Reuss J, et al. Effects of glaucoma drugs on ocular hemodynamics in normal tension glaucoma: a randomized trial comparing bimatoprost and latanoprost with dorzolamide. $B M C$ Ophthalmol. 2005;5:6.

174. Bayer A, Weiler W, Oeverhaus U, Skrotzki FE, Stewart WC; Xplore Observation Group. Two-year follow-up of latanoprost $0.005 \%$ monotherapy after changing from previous glaucoma therapies. J Ocul Pharmacol Ther. 2004;20(6):470-478.

175. Petounis A, Mylopoulos N, Kandarakis A, Andreanos D, Dimitrakoulias N. Comparison of the additive intraocular pressurelowering effect of latanoprost and dorzolamide when added to timolol in patients with open-angle glaucoma or ocular hypertension: a randomized, open-label, multicenter study in Greece. J Glaucoma. 2001;10(4):316-324.

176. Diestelhorst M. German Latanoprost Study Group. The additive intraocular pressure-lowering effect of latanoprost $0.005 \%$ daily once and pilocarpine $2 \%$ t.i.d. in patients with open-angle glaucoma or ocular hypertension. A 6-month randomized, multicenter study. German Latanoprost Study Group. Graefes Arch Clin Exp Ophthalmol. 2000;238(5):433-439.

177. Diestelhorst M, Nordmann J, Toris CB. Combined therapy of pilocarpine or latanoprost with timolol versus latanoprost monotherapy Surv Ophthalmol. 2002;47 Suppl 1:S155-S161.

178. Toris CB, Zhan GL, Zhao J, Camras CB, Yablonski ME. Potential mechanism for the additivity of pilocarpine and latanoprost. $\mathrm{Am} \mathrm{J}$ Ophthalmol. 2001;131(6):722-728.

179. Toris CB, Alm A, Camras CB. Latanoprost and cholinergic agonists in combination. Surv Ophthalmol. 2002;47 Suppl 1):S141-S147.

180. Friström B, Nilsson SEG. Interaction of PhXA41, a new prostaglandin analogue, with pilocarpine: a study on patients with elevated intraocular pressure. Arch Ophthalmol. 1993;111(5):662-625.

181. Kent AR, Vroman DT, Thomas TJ, Hebert RL, Crosson CE. Interaction of pilocarpine with latanoprost in patients with glaucoma and ocular hypertension. J Glaucoma. 1999;8(4):257-262.

182. Patelska B, Greenfield DS, Liebmann JM, et al. Latanoprost for uncontrolled glaucoma in a compassionate case protocol. Am J Ophthalmol. 1997; 124(3):279-286.

183. Shin DH, McCracken MS, Bendel RE, et al. The additive effect of latanoprost to maximum-tolerated medications with low-dose, high-dose, or no pilocarpine therapy. Ophthalmology. 1999;106(2):386-390.

184. Susanna R, Nicolela MT, Oga E. Additive effect of latanoprost to the combination of timolol and dorzolamide. J Glaucoma. 2000;9(2) 183-186.

185. O'Connor DJ, Martone JF, Mead A. Additive intraocular pressure lowering effect of various medications with latanoprost. Am J Ophthalmol. 2002;133(6):836-837.

186. Cheng JW, Xi GL, Wei RL, Cai JP, Li Y. Efficacy and tolerability of latanoprost compared to dorzolamide combined with timolol in the treatment of patients with elevated intraocular pressure: a metaanalysis of randomized, controlled trials. J Ocul Pharmacol Ther. 2009;25(1):55-64.

187. Bron A. For the Groupe Europeen d'etudes du Latanoprost. Comparison of latanoprost monotherapy with timolol-dorzolamide combination in patients with open-angle glaucoma or ocular hypertension. $\mathrm{J} \mathrm{Fr}$ Ophthalmol. 2002;25(6):604-608.

188. Honrubia FM, Larsson LI. The European Latanoprost Study Group. A comparison of the effect of intraocular pressure of latanoprost $0.005 \%$ and fixed combination of dorzolamide $2 \%$ and timolol $0.5 \%$ in patients with open-angle glaucoma. Acta Ophthalmol Scand. 2002;80(6):635-641.
189. Konstas AG, Kozobolis VP, Tersis I, Leech J, Stewart WC. The efficacy and safety of the timolol/dorzolamide fixed combination vs latanoprost in exfoliation glaucoma. Eye. 2003;17(1):41-46.

190. Konstas AG, Papapanos P, Tersis I, Houliara D, Stewart WC. Twentyfour-hour diurnal curve comparison of commercially available latanoprost $0.005 \%$ versus the timolol and dorzolamide fixed combination. Ophthalmology. 2003;110(7):1357-1360.

191. Susanna R Jr, Sheu WP. Latin American Glaucoma Society. Comparison of latanoprost with fixed-combination dorzolamide and timolol in adult patients with elevated intraocular pressure: an eight-week, randomized, open-label, parallel-group, multicenter study in Latin America. Clin Ther. 2004;26(5):755-768.

192. Sakai H, Shinjyo S, Nakamura Y, et al. Comparison of latanoprost monotherapy and combined therapy of $0.5 \%$ timolol and $1 \%$ dorzolamide in chronic primary angle-closure glaucoma (CACG) in Japanese patients. J Ocul Pharmacol Ther. 2005;21(6):483-489.

193. Chiselita D, Antohi I, Medvichi R, Danielescu C. Comparative analysis of the efficacy and safety of latanoprost, travoprost and the fixed combination timolol-dorzolamide: a prospective, randomized, masked, cross-over design study. Oftalmologia. 2005;49(3):39-45.

194. Rismanchian A, Eslami F, Moeini H, Attarzade H, Naderibeni A. Efficacy of the latanoprost versus timolol/dorzolamide combination therapy in patients with primary open-angle glaucoma. Saudi Med Journal. 2008;29(3):384-387.

195. Konstas AG, Kozobolis VP, Tsironi S, et al. Comparison of the 24-hour intraocular pressure-lowering effects of latanoprost and dorzolamide/ timolol fixed combination after 2 and 6 months of treatment. Ophthalmology. 2008;115(1):99-103.

196. Fechtner RD, McCarroll KA, Lines CR, Adamsons IA. Efficacy of the Dorzolamide/timolol fixed combination versus latanoprost in the treatment of ocular hypertension or glaucoma: combined analysis of pooled data from two large randomized observer and patient-masked studies. J Ocular Pharm Ther. 2005;21(3):242-249.

197. Konstas AG, Boboridis K, Tzetzi D, et al. Twenty-four-hour control with latanoprost-timolol fixed combination therapy vs latanoprost therapy. Arch Ophthalmol. 2005;123(7):898-902.

198. Webers CA, van der Valk R, Schouten JS, et al. Intraocular pressurelowering effect of adding dorzolamide or latanoprost to timolol. A meta-analysis of randomized clinical trials. Ophthalmology. 2007;114(1):40-46.

199. Brandt JD, Cantor LB, Katz LJ, et al. Bimatoprost/timolol fixed combination: a 3 month double-masked, randomized parallel comparison to its individual components in patients with glaucoma or ocular hypertension. J Glaucoma. 2008;17(3):211-216.

200. European Agency for the Evaluation of Medicinal Products(EMEA). European public assessment report: scientific discussion of Ganfort. http://www.emea.eu.int/humandocs/Humans/EPAR/ganfort/ganfort. htm. Accessed April 19, 2010.

201. Hommer A, Ganfort Investigators Group I. A double-masked, randomized, parallel comparison of a fixed combination of bimatoprost $0.03 \% /$ timolol $0.5 \%$ with non-fixed combination use in patients with glaucoma or ocular hypertension. Eur J Ophthalmology. 2007;17(1): 53-62.

202. Martinez A, Sanchez M. A comparison of the safety and intraocular pressure lowering of bimatoprost/timolol fixed combination versus latanoprost/timolol fixed combination in patients with open-angle glaucoma. Curr Med Res Opin. 2007;23:1023-1032.

203. Centofanti M, Oddone F, Vertrugno M, et al. Efficacy of the fixed combinations of bimatoprost or latanoprost plus timolol in patients uncontrolled with prostaglandin monotherapy: a multi-centre, randomized, investigator-masked, clinical study. Eur J Ophthalmol. 2009;19(1):66-71.

204. Konstas AG, Mikropoulos D, Haidich AB, Ntampos KS, Stewart WC. Twenty-four hour intraocular pressure control with the travoprost/ timolol maleate fixed combination compared with travoprost when both are dosed in the evening in primary open-angle glaucoma. $\mathrm{Br} J$ Ophthalmol. 2009;93(4):481-485. 
205. Schuman JS, Katz GJ, Lewis RA, et al. Efficacy and safety of a fixed combination of travoprost $0.004 \%$ /timolol $0.5 \%$ ophthalmic solution once daily for open-angle glaucoma or ocular hypertension. $\mathrm{Am} \mathrm{J}$ Ophthalmol. 2005;140(2):242-250.

206. Hughes BA, Bacharach J, Craven ER, et al. A three-month, multicenter, double-masked study of the safety and efficacy of travoprost $0.004 \%$ / timolol $0.5 \%$ ophthalmic solution and timolol $0.5 \%$ dosed concomitantly in subjects with open-angle glaucoma or ocular hypertension. J Glaucoma. 2005;14(5):392-399.

207. Henry JC, Kessler TL, Mallick S, et al. Travoprost/timolol Study Group. Comparison of the safety and IOP-lowering efficacy of travoprost $0.004 \%$ / timolol $0.5 \%$ fixed combination to the concomitant administration of Xalatan and timolol 0.5\% [Abstr 446] ARVO, Fort Lauderdale, 2006.

208. Rhee DJ, Peace JH, Mallick S, Landry TA, Bergamini MV. A study of the safety and efficacy of travoprost $0.004 \% /$ timolol $0.5 \%$ ophthalmic solution compared to latanoprost $0.005 \%$ and timolol $0.5 \%$ dosed concomitantly in patients with open-angle glaucoma or ocular hypertension. Clin Ophthalmol. 2008;2(2):313-319.

209. Teus MA, Miglior S, Laganovska G, et al. Efficacy and safety of travoprost/timolol vs dorzolamide/timolol in patients with open-angle glaucoma or ocular hypertension. Clin Ophthalmol. 2009;3:629-636.

210. Denis P, Lafuma A, Jeanbat V, Laurendeau C, et al. Intraocular pressure control with latanoprost/timolol and travoprost/timolol fixed combinations: a retrospective, multicentre, cross-sectional study. Clin Drug Investig. 2008;28(12):767-776.

211. Zimmerman TJ, Hahn SR, Gelb L, Tan H, Kim EE. The impact of ocular adverse effects in patients treated with topicl prostaglandin analogs: changes in prescription patterns and patient persistence. $J O c$ Pharm Ther. 2009;25(2):145-151.

212. Honrubia F, Garcia-Sanchez J, Polo V, Matinez de la Casa JM, Soto J. Conjunctival hyperaemia with the use of latanoprost versus other prostaglandin analogues in patients with ocular hypertension or glaucoma: a meta-analysis of randomized control trials. Br J Ophthalmol. 2009;93(3):316-321.

213. Stjernschantz JW. From PGF2 $\alpha$-isopropyl ester to latanoprost: a review of the development of Xalatan. The Proctor lecture. Invest Ophthalmol Vis Sci. 2001;42(6):1134-1145.

214. Wistrand PJ, Stjernschantz J, Olsson K. The incidence and time-course of latanoprost-induced iridial pigmentation as a function of eye color. Surv Ophthalmol. 1997;41 Suppl 2:S129-S138.

215. Alm A, Schoenfelder J, McDermott J. A 5-year, multicentre, openlabel, safety study of adjunctive latanoprost therapy for glaucoma. Arch Ophthalmol. 2004;122(7):957-965.

216. Grierson I, Jonsson M, Cracknell K. Latanoprost and pigmentation. Jpn J Ophthalmol. 2004;48(6):602-612.

217. Chou SY, Chou CK, Kuang TM, et al. Incidence and severity of iris pigmentation on latanoprost-treated glaucoma eyes. Eye. 2005;19(7):784-787

218. Latanoprost-Induced iris Pigmentation Study Group. Incidence of a latanoprost-induced increase in iris pigmentation in Japanese eyes. Jpn J Ophthalmol. 2006;50(2):96-99.

219. Lindquist NG, Larsson BS, Stjernschantz J. Increased pigmentation of iridial melanocytes in primates induced by a prostaglandin analogue. Exp Eye Res. 1999;69:431-436.

220. Pfeiffer N, Grierson I, Goldsmith H, et al. Histological effects in the iris after 3 months of latanoprost therapy: The Mainz 1 Study. Arch Ophthalmol. 2001;119(2):191-196.

221. Prota G, Vincensi MR, Napolitano A, Selen G, Stjernschantz J. Latanoprost stimulates eumelanogenesis in iridial melanocyte of cynomolgus monkeys. Pigment Cell Res. 2000;13:147-150.

222. Stjernschantz JW, Albert DM, Hu DN, Drago F, Wistrand PJ. Mechanism and clinical significance of prostaglandin-induced iris pigmentation. Surv Ophthalmol. 2002;47 Suppl 1:S162-S175.

223. Bito LZ. Prostaglandins: a new approach to glaucoma management with a new, intriguing side effect. Surv Ophthalmol. 1997;41 Suppl 2:S1-S14

224. Grierson I, Cracknell KP, Pfeiffer N. The iris after prostanoid treatment. Curr Opin Ophthalmol. 2001;12(2):112-118.
225. Albert DM, Green WR, Zimbric ML, et al. Iris melanocyte histopathologic features of latanoprost- and non-latanoprost treated patients. Arch Ophthalmol. 2004;122(11):1680-1685.

226. Hu DN, Stjernschantz J, McCormick SA. Effect of prostaglandins A, $\mathrm{E}_{1}, \mathrm{~F}_{2} \alpha$ and latanoprost on cultured human iridal melanocytes. Exp Eye Res. 2000;70(1):113-120.

227. Loeffler KU, Sahm M, Spitznas M. Short-time application of latanoprost does not stimulate melanogenesis in bovine ocular melanincontaining cells in vitro. Ophthalmic Res. 2001;33(2):102-106.

228. Alm A, Grierson I, Shields MB. Side effects associated with prostaglandin analog therapy. Surv Ophthalmol. 2008;53 Suppl 2:S93-S105.

229. Johnstone MA. Hypertrichosis and increased pigmentation of eyelashes and adjacent hair in the region of the ipsilateral eyelids of patients treated with unilateral topical latanoprost. Am J Ophthalmol. 2001;132(4);472-484.

230. Wand M. Latanoprost and hyperpigmentation of eyelashes. Arch Ophthalmol. 1997;115(9):1206-1208.

231. Chiba T, Kashiwagi K, Chiba N, et al. A prospective study of iridal pigmentation and eyelash changes due to ophthalmic treatment with latanoprost. Jpn J Ophthalmol. 2004;48(2):141-147.

232. Shaikh MY, Bodla AA. Hypertrichosis of the eyelashes from prostaglandin analog use: a blessing or a bother to the patient? J Ocul Pharmacol Ther. 2006;22(1):76-77.

233. Johnstone MA, Albert DM. Prostaglandin-induced hair growth. Surv Ophthalmol. 2002;47 Suppl 10);S185-S202.

234. Chen CS, Wells J, Craig JE. Topical prostaglandin F(2 alpha)analog induced poliosis. Am J Ophthlamol. 2004;137(5):965-966.

235. Waheed K, Laganowski H. Bilateral poliosis and granulomatous anterior uveitis associated with latanoprost use and apparent hypotrichosis onits withdrawal. Eye. 2001;15(Pt 3):347-349.

236. Herndon LW, Robert D Williams, Wand M, Asrani S. Increased periocular pigmentation with ocular hypotensive lipid use in African Americans. Am J Ophthalmol. 2003;135(5):713-715.

237. Kook MS, Lee K. Increased eyelid pigmentation associated with latanoprost use. Am J Ophthalmol. 2000;129(6):804-806.

238. Wand M, Ritch R, Isbey EK, et al. Latanoprost and periocular skin changes. Arch Ophthalmol. 2001;119(4):614-615.

239. Doshi M, Edward DP, Osmanovic S. Clinical course of bimatoprostinduced periocular skin changes in Caucasians. Ophthalmology. 2006;113(11):1961-1967.

240. Galloway GD, Eke T, Broadway DC. Periocular cutaneous pigmentary changes associated with bimatoprost use. Arch Ophthalmol. 2005;123(11):1609-1610.

241. Chen J, Dinh T, Woodward DF, et al. Bimatoprost: mechanism of ocular surface hyperaemia associated with topical therapy. Cardiovasc Drug Res. 2005;23(3):231-246.

242. Easthope SE, Perry CM. Topical bimatoprost: a review of its use in open-angle glaucoma and ocular hypertension. Drugs Aging. 2002;19(3):231-248.

243. Kapur R, Osmanovic S, Toyran S, Edward DP. Bimatoprost induced periocular skin hyperpigmentation: Histopathological study. Arch Ophthalmol. 2005;123(11):1541-1546.

244. Abdel-Malek ZA, Swope VB, Amornsiripanitch N, et al. In vitro modulation of proliferation and melanisation of S91 melanoma cells by prostaglandins. Cancer. Res 1987;31:41-46.

245. Sodhi PK, Verma L, Ratan SK. Increased periocular pigmentation with ocular hypotensive lipid use in African Americans. Am J Ophthalmol. 2004;137(4):783.

246. Miyake K, Sugiyama S, Norimatsu I, Ozawa T. Prevention of cystoid macular oedema after lens extraction by topical indomethacin (III) radioimmunoassay measurement of prostaglandins in the aqueous during and after lens extraction procedures. Albrecht Von Graefes Arch Klin Exp Ophthalmol. 1978;209:83-88.

247. Weisz JM, Bressler NM, Bressler SB. Ketorolac treatment of pseudophakic cystoid macular oedema identified more than 24 months after cataract extraction. Ophthalmology. 1999;106(9): 1656-1659. 
248. Miyake K, Ibaraki N. Prostaglandins and cystoid macular edema. Surv Ophthalmol. 2002;47 Suppl 1:S203-S218.

249. Miyake K, Ota I, Maekubo K, Ichihashi S, Miyake S. Latanoprost accelerates disruption of the blood aqueous barrier and the incidence of angiographic cystoid macular oedema in early post-operative pseudophakias. Arch Ophthalmol. 1999;117(1):34-40.

250. Schumer RA, Camras CB, Mandahl AK. Latanoprost and cystoid macular oedema: is there a causal relation? Curr Opin Ophthalmol. 2000;11(2):94-100.

251. Miyake K, Shirasawa E, Hikita M, et al. Synthesis of prostaglandin E inrabbit eyes with topically applied epinephrine. Invest Ophthalmol Vis Sci. 1988;29(2):332-334.

252. Ayyala RS, Cruz DA, Margo CE, et al. Cystoid macular oedema associated with latanoprost in aphakic and pseudophakic eyes. Am J Ophthalmol. 1998;126(4):602-604.

253. Moroi SE, Gottfredsdottir MS, Schteingart MT, et al. Cystoid macular oedema associated with latanoprost therapy in a case series of patients with glaucoma and ocular hypertension. Ophthalmology. 1999;106(5): 1024-1029.

254. Rowe JA, Hattenhauer MG, Herman DC. Adverse side effects associated with latanoprost. Am J Ophthalmol. 1997;124(5):683-685.

255. Wand M, Gaudio AR. Cystoid macular oedema associated with ocular hypotensive lipids. Am J Ophthalmol. 2002;133(3):403-405.

256. Warwar RE, Bullock JD, Ballal D. Cystoid macular oedema and anterior uveitis associated with latanoprost use. Experience and incidence in a retrospective review of 94 patients. Ophthalmology. 1998;105(2):263-268.

257. Lima MC, Paranhos A, Salim S, et al. Visually significant cystoid macular oedema in pseudophakic and aphakic patients with glaucoma receiving latanoprost. J Glaucoma. 2000;9(4):317-321.

258. Wand M, Gaudio AR, Shields MB. Latanoprost and cystoid macular oedema in high risk aphakic or pseudophakic eyes. $J$ Cataract Refract Surg. 2001;27(9):1397-1401

259. Chang JH, McCluskey P, Missotten T, et al. Use of ocular hypotensive prostaglandin analogues in patients with uveitis: does their use increase anterior uveitis and cystoid macular oedema? $\mathrm{Br} J$ Ophthalmol. 2008;92(7):916-921.

260. Furuichi M, Chiba T, Abe K, et al. Cystoid macular oedema associated with topical latanoprost in glaucomatous eyes with a normally functioning blood-ocualr barier. J Glaucoma. 2001;10(3):233-236.

261. Fechtner RD, Khouri AS, Zimmerman TJ, et al. Anterior uveitis associated with latanoports. Am J Ophthalmol. 1998;126(1):37-41.

262. Linden C, Alm A. The effect on intraocular pressure of latanoprost once or four times daily. Br J Ophthalmol. 2001;85(10):1163-1166.

263. Markomichelakis NN, Kostakou A, Halkiadakis I, et al. Efficacy and safety of latanoprost in eyes with uveitic glaucoma. Graefes Arch Clin Exp Ophthalmol. 2009;247(6):775-780.

264. Wand M, Gilbert CM, Liesegang TJ. Latanoprost and herpes simplex keratitis. Am J Ophthalmol 1999;127(5):602-604.

265. Kroll DM, Schuman JS. Reactivation of herpes simplex virus keratitis after initiating bimatoprost treatment for glaucoma. Am J Ophthalmol. 2002;133(3):401-403.

266. Kaufman HE, Varnell ED, Thompson HW. Latanoprost increases the severity and recurrence of herpetic keratitis in the rabbit. $A m J$ Ophthalmol 1999;127(5):531-536.

267. Bean G, Reardon G, Zimmerman TJ. Association between ocular herpes simplex virus and topical ocular hypotensive therapy. J Glaucoma. 2004;13(5):361-364.

268. Browning DJ, Perkins SL, Lark KK. Iris cyst secondary to latanoprost mimicking iris melanoma. Am J Ophthalmol. 2003;135(3): 419-421.

269. Krohn J, Hove VK. Iris cysts associated with topical administration of latanoprost. Am J Ophthalmol. 1999;127(1):91-93.

270. Lai IC, Kuo MT, Teng LM. Iris pigment epithelial cyst induced by topical administration of latanoprost. Br J Ophthalmol. 2003;87(3):366.

271. Pruthi S, Kashani S, Ruben S. Bilateral iris cyst secondary to topical latanoprost. Acta Ophthalmol. 2008;86(2):233-234.
272. Sodhi PK. Iris cyst secondary to latanoprost mimicking iris melanoma. Am J Ophthalmol. 2003;136(4):80, author reply 780-781.

273. Hedner J, Everts B, Mooller CS. Latanoprost and respiratory function in asthmatic patients: randomized, double-masked, placebocontrolled crossover evaluation. Arch Ophthalmol. 1999;117(10): 1305-1309.

274. Susanna R, Medeiros FA. The pros and cons of different prostanoids in the medical management of glaucoma. Curr Opin Ophthalmol. 2001;12(2):149-156

275. Swedish Adverse Drug Reactions Advisory Committee. Respiratory tract reactions to latanoprost. Bull SARAC. 1998;67:4-5.

276. Pfizer. Xalatan (Latanoprost $0.005 \%$ ) ophthalmic solution: prescribing information. Available online. 2009.

277. Mitra M, Chang B, James T. Drug points. Exacerbation of angina associated with latanoprost. $B M J .2001 ; 323: 783$.

278. Peak AS, Sutton BM. Systemic adverse effects associated with topically applied latanoprost. Ann Pharmacother. 1998;32(4):504-505.

279. Weston BC. Migraine headache associated with latanoprost. Arch Ophthalmol. 2001;119(2):300-301.

280. Alm A, Widengard I, Kjellgren D, et al. Latanoprost administration once daily caused a maintained reduction of intraocular pressure in glaucoma patients treated concomitantly with timolol. Br J Ophthalmol. 1995;79(1):12-16.

281. Hylton C, Robin AL. Update on prostaglandin analogs. Curr Opin Ophthalmol. 2003;14(2):65-69.

282. Herndon LW, Asrani SG, Williams GH, et al. Paradoxical intraocular pressure elevation after combined therapy with latanoprost and bimatoprost. Arch Ophthalmol. 2002;120(6):847-849.

283. Perry CM, McGavin JK, Culy CR, Ibbotson Y. Latanoprost. An update of its use in glaucoma and ocular hypertension. Drugs Aging. 2003; 20(8):597-630.

284. Goldberg I, Li XY, Selaru P, Paggiarino D. A 5-year, randomized, open-label safety study of latanoprost and usual care in patients with open-angle glaucoma or ocular hypertension. Eur J Ophthalmol. 2008; 18(3):408-416

285. Weinreb RN. Compliance with medical treatment in glaucoma. J Glaucoma. 1992;1:134-136.

286. Reardon G, Schwartz GF, Mozaffari E. Patient persistency with topical ocular hypotensive therapy in a managed care population. Am J Ophthalmol. 2004;137 Suppl 1:S3-S12.

287. Gurwitz JH, Glynn RJ, Manane M, et al. Treatment for glaucoma: adherence by the elderly. Am J Public Health. 1993;83(5):711-716.

288. Stewart WC, Kruft B, Nelson LA, Stewart JA. Ophthalmologist attitudes regarding fixed combination treatment for glaucoma in the European Union. Eur J Ophthalmol. 2009;19(4):588-593.

289. Baudouin C. Side effects of antiglaucomatous drugs on the ocular surface. Curr Opin Ophthalmol. 1996;7(2):80-86.

290. Hamacher T, Airksinen J, Saarela V, et al. Efficacy and safety levels of preserved and preservative free tafluprost are equivalent in patients with glaucoma or ocular hypertension: results from a pharmacodynamics analysis. Acta Ophthalmol Suppl (Oxf). 2008;242: $14-19$.

291. Uusitalo H, Kaarniranta K, Ropo A. Pharmacokinetics, efficacy and safety profiles of preserved and preservative-free tafluprost in healthy volunteers. Acta Ophthalmol Suppl (Oxf). 2008;242:7-13.

292. Gross RL, Peace JH, Smith SE, et al. Duration of IOP reduction with travoprost BAK-free solution. J Glaucoma. 2008;17(3):217-222.

293. Lewis RA, Katz G, Weiss MJ, et al. Travoprost $0.004 \%$ with and without benzalkonium chloride: a comparison of safety and efficacy. J Glaucoma. 2007;16(1):98-103.

294. Schmier, Halpern MT, Jones ML. The economic implications of glaucoma. A literature review. Pharmacoeconomics. 2007;25(4): 287-308.

295. Balkrishnan R, Bond JB, Byerly WG, Camacho FT, Anderson RT. Medication-related predictors of health-related quality of life in glaucoma patients enrolled in a medicare health maintenance organization. Am J Geriatr Pharmacother. 2003;1(2):75-81. 
296. Haverkamp F, Wuensch S, Fuchs M, et al. Intraocular pressure, safety and quality of life in glaucoma patients switching to latanoprost from adjunctive and monotherapy treatments. Eur J Ophthalmol. 2004;14(5):407-415.

297. Dunker S, Schmuker A, Maier H. Latanoprost/Timolol Fixed Combination Study Group. Tolerability, quality of life, and persistency of use in patients with glaucoma who are switched to the fixed combination of latanoprost and timolol. Adv Ther. 2007;24(2):376-386.

298. Pillunat L, Larsson LI, the European and Canadian Latanoprost Study Group. Intraocualr pressure after replacement of current dual therapy with latanoprost monotherapy in patients with open-angle glaucoma. Br J Ophthalmol. 2003;87(12):1492-1496.

299. Zimmerman TJ, Stewart WC. Latanoprost Axis Study Group. Intraocular pressure, safety, and quality of life in glaucoma patients switching to latanoprost from monotherapy treatments. J Ocul Pharmacol Ther. 2003;19(5):405-415.

300. Tsai JC. A comprehensive perspective on patient adherence to topical glaucoma therapy. Ophthalmology. 2009;116 Suppl 11:S30-S36.

301. Heijl A, Leske MC, Bengtsson B, et al. Reduction of intraocular pressure and glaucoma progression: results from the early manifest glaucoma trial. Arch Ophthalmol. 2002;120(10):1268-1279.
302. Collaborative Normal-Tension Glaucoma Study Group/the effectiveness of intraocular pressure reduction in the treatment of normal-tension glaucoma. Am J Ophthalmol. 1998;126(4):498-505.

303. AGIS Investigators. The Advanced Glaucoma Intervention Study(AGIS): 7. The relationship between control of intraocular pressure and visual field deterioration. Am J Ophthalmol. 2001;130(4): 429-440.

304. American Academy of Ophthalmology. Preferred practice pattern: primary open-angle glaucoma. San Francisco (CA): American Academy of Ophthalmology, 2005.

305. European Glaucoma Society. Terminology and guidelines for glaucoma. 3rd ed. Savona, Italy: Dogma 2008.

306. Carroll SC, Gaskin BJ, Goldberg I, Danesh-Meyer HV. Glaucoma prescribing trends in Australia and New Zealand. Clin Experiment Ophthalmol. 2006;34(3):213-218.

307. Curran MP, Orman JS. Bimatoprost/timolol: A review of its use in glaucoma and ocular hypertension. Drugs Aging. 2009;26(2):169-184.
Clinical Ophthalmology

\section{Publish your work in this journal}

Clinical Ophthalmology is an international, peer-reviewed journal covering all subspecialties within ophthalmology. Key topics include: Optometry; Visual science; Pharmacology and drug therapy in eye diseases; Basic Sciences; Primary and Secondary eye care; Patient Safety and Quality of Care Improvements. This journal is indexed on

\section{Dovepress}

PubMed Central and CAS, and is the official journal of The Society of Clinical Ophthalmology (SCO). The manuscript management system is completely online and includes a very quick and fair peer-review system, which is all easy to use. Visit http://www.dovepress.com/ testimonials.php to read real quotes from published authors. 